MUSICA THEORICA 2021, V. 6.1

SCIENTIFIC ARTICLE

DOI: $10.52930 / \mathrm{mt} . v 6 \mathrm{i} 1.164$

Data do recebimento: 07/07/2021

Data da aprovação final: 13/08/2021

\title{
O atonalismo, a dodecafonia e a música nacional de Eunice Katunda em Variações sobre um tema popular e Quatro epígrafes
}

\author{
Atonalism, dodecaphony, and national music by Eunice Katunda in \\ Variações sobre um tema popular and Quatro epígrafes
}

\author{
Marisa Milan Candido \\ Amilcar Zani Netto \\ Eliana Monteiro da Silva \\ Universidade de São Paulo
}

\begin{abstract}
Resumo: Este artigo discute o emprego de técnicas e procedimentos da música atonal e dodecafônica pela compositora brasileira Eunice Katunda nas obras Variações sobre um tema popular e Quatro epígrafes, compostas, respectivamente, em 1943 e 1948. Partindo da pergunta feita pela compositora em texto intitulado Atonalismo, dodecafonia e música nacional (1952)1 "É possível fazer música atonal, ou dodecafônica, de caráter nacional?", propõe-se uma reflexão sobre os caminhos percorridos por Eunice Katunda nas duas primeiras fases de sua trajetória composicional - a Fase de Formação (até 1945) e a Fase Música Viva (1946-50)², quando foram compostas as obras citadas. Estas obras foram analisadas de acordo com bibliografia condizente com os períodos abordados e comparadas a outras composições estudadas e/ou apresentadas por Eunice Katunda em recitais, tais como os ciclos Guia Prático, Brinquedo de Roda e Cirandas, de Heitor Villa-Lobos, e aos procedimentos usados por Camargo Guarnieri e Hans-Joachim Koellreutter.
\end{abstract}

Palavras-chave: Eunice Katunda. Atonalismo. Dodecafonismo. Nacionalismo. Compositora Brasileira.

${ }^{1}$ Cf. Katunda apud Kater 2020, p. 157.

2 A divisão da obra composicional de Eunice Katunda em 4 fases, intituladas Fase de Formação, Fase Música Viva, Fase Nacionalista e Fase Final, é um dos objetivos da pesquisa de Doutorado em andamento de Marisa Milan Candido. Essa divisão já foi apresentada em publicações como Zani; Monteiro da Silva; Candido (2019, p. 117), entre outros. 
MUSICA THEORICA Revista da Associação Brasileira de Teoria e Análise Musical 2021, v. 6, n. 1, p. 100-132 - Journal of the Brazilian Society for Music

Abstract: This article examines the use of atonal and dodecaphonic music techniques and procedures by the Brazilian composer Eunice Katunda in the works Variations on a popular theme and Four epigraphs, composed, respectively, in 1943 and 1948. Starting from the enquire placed by the composer in a text entitled Atonalism, dodecaphony and national music (1952) "Is it possible to compose atonal or dodecaphonic music of national character?", the article poses a reflection about the paths taken by Eunice Katunda in the first and second phases of her compositional trajectory - a Formation Phase (until 1945) and the Música Viva Phase (194650 ), when the aforementioned works were composed. These works were analyzed according to pertinent bibliography and compared to other compositions studied and/or performed by Eunice Katunda in recitals, such as the series Guia Prático, Brinquedo de Roda and Cirandas, by Heitor Villa-Lobos, and to the procedures used by Camargo Guarnieri and Hans-Joachim Koellreutter.

Keywords: Eunice Katunda. Atonalism. Dodecaphonism. Nationalism. Brasilian composer.

\section{Introdução}

A primeira metade do século $X X$ testemunhou o esforço da maioria dos países latino-americanos por criar uma cultura e uma arte de caráter nacional, que afirmasse a identidade de cada um deles, bem como a do continente como bloco de língua latina - utilizando aqui o conceito atribuído a Maximiliano de Habsburgo para o termo América Latina3. Gérard Béhague (apud Bethell 1999, p. 339), que apontou a divisão do século XX em duas partes iguais, reconhecendo como correntes basilares o nacionalismo e o que chamou de experimentalismo (ambas denominações bastante amplas e sujeitas a controvérsias), justificou o crescimento do nacionalismo como estética e política pela reação à grande dependência social e econômica dos países latino-americanos em relação à Europa e aos Estados Unidos naquele período.

Por sua vez, ao menos no caso do Brasil, Anaïs Fléchet (2011, p. 231) observa a existência de uma diplomacia musical que apoiaria e legitimaria a cristalização de uma estética nacionalista desde que o país recebeu "suas primeiras palmas internacionais, com a estreia de Il Guarany [de Antônio Carlos Gomes] na Scala de Milão na noite do dia 19 de março de 1870". De acordo com a pesquisadora, "essa ópera foi tradicionalmente apontada como a origem do

\footnotetext{
${ }^{3}$ De acordo com Funes (1996 apud Monteiro da Silva 2014), Maximiliano de Habsburgo chegou a este continente enviado por Napoleão III da França com a missão de formar um império apoiado pelos países de língua latina para deter o avanço dos Estados Unidos rumo ao sul das Américas.
} 
CANDIDO, M. et al. $\quad \mathrm{O}$ atonalismo, a dodecafonia e a música nacional de Eunice Katunda em Variações sobre um tema popular e Quatro epígrafes

nacionalismo musical brasileiro", motivando, inclusive, a entrada da música "de maneira oficial no corpo diplomático, com a nominação de Brazílio Itiberê da Cunha" em 1871 (ibid.).

Entre a nomeação de Itiberê como uma espécie de diplomata musical brasileiro na Europa e a apresentação de concertos de Heitor Villa-Lobos em Paris, em 1924 - passando pela criação da Sociedade Internacional de Música (SIM) em 1899, em que se divulgou a obra de compositores como Henrique Oswald e Alberto Nepomuceno -, o interesse europeu despertado pela música brasileira de caráter nacional (que trazia como elemento o exotismo que aguçava a curiosidade pelas culturas tropicais) reforçou, progressivamente, a continuidade do uso de materiais oriundos do que se entendia como folclore popular por compositores e compositoras.

Sendo a França consumidora desta arte e aliada da diplomacia brasileira4, não admira que autores como Villa-Lobos assimilassem em sua música técnicas influenciadas pelo impressionismo francês - como a colagem e justaposição de materiais diversos 5 e o uso de coleções referenciais como a de tons inteiros e a pentatônica ${ }^{6}$ - obtendo, a partir destas práticas, toda uma nova gama de cores

\footnotetext{
${ }^{4}$ Neste período Luiz Martins de Souza Dantas era embaixador brasileiro em Paris.

${ }^{5} \mathrm{O}$ uso do termo colagem é aqui emprestado das técnicas utilizadas na música concreta e eletroacústica, que na década de 1960 manipularam materiais sonoros previamente criados (no caso da música concreta, gravados, e na música eletroacústica, produzidos eletronicamente) de forma a criar novas sonoridades por meio de sua justaposição e/ou sobreposição (Barrièrre 1996, p. 16, apud Silveira 2012, p. 81). Alexandre Ficagna (2008, p. 5) aponta a presença deste raciocínio já no séc. XIX, quando compositores impressionistas como Claude Debussy teriam feito uso deste tipo de prática utilizando sonoridades do tonalismo sem as relações hierárquicas características daquele sistema, concebendo-as como timbres, materiais dotados de expressão própria que serão organizados no discurso musical de maneira descontínua. Maria Lucia Pascoal (1989, p. 278) aponta, nos Prelúdios de Debussy, "um tratamento diferente das ideias: elas são transpostas, justapostas, aparecem em superposição e em fragmentos, formando assim uma nova estrutura de desenvolvimento".

${ }^{6}$ Segundo Vasconcelos (2014, p. 13), coleções (ou escalas) referenciais são conjuntos de classes de alturas não ordenados "dos quais se retiram conjuntos menores e que atuam como elementos unificadores, por suas propriedades abstratas específicas". O autor cita como exemplos a coleção diatônica, de tons inteiros, octatônica, hexatônica, pentatônica, acústica e cromática.
} 
MUSICA THEORICA Revista da Associação Brasileira de Teoria e Análise Musical 2021, v. 6, n. 1, p. 100-132 - Journal of the Brazilian Society for Music

harmônicas inusitadas". Definindo-a como "atonalismo modal", esta corrente derivada da escola franco-russa é vista por Coelho de Souza (2009, p. 141) como

[um] novo principio de polimodalismo que diferencia a música desses compositores da música modal folclórica e erudita anterior à tonalidade. Esta corrente do atonalismo tem enorme importância para a música brasileira, [uma vez que] compositores modernistas brasileiros, como Villa-Lobos, não apenas foram influenciados, mas participaram diretamente do desenvolvimento dessa linguagem em obras-primas como Rudepoema e Uirapuru.

A preocupação de criar uma música de concerto que fosse, ao mesmo tempo, brasileira e moderna, dominou a discussão teórica e a atividade prática durante a primeira metade do século XX. De acordo com Barros (2013, p. 3), tal música deveria conjugar "as fontes folclóricas - cujo caráter brasileiro era indiscutível na época - com a proficiência técnica desenvolvida no contato com a alta cultura europeia".

Isso significou, para alguns autores e autoras, mesclar materiais de origem popular a elementos da chamada musica de concerto tradicional - baseada, por um lado, no contraponto dos séculos XVI e XVII aliado a técnicas de variação e desenvolvimento motívico, características da música germânica dos séculos XVIII e XIX, e, por outro, nos procedimentos de colagem e justaposição de materiais antagônicos derivados da música franco-russa da virada do século XIX para o XX.

Entre estes(as) criadores(as) encontrava-se Eunice do Monte Lima Catunda, conhecida no meio musical como Eunice Katunda.

\section{Eunice Katunda e suas duas primeiras fases composicionais}

Eunice Katunda (Rio de Janeiro, 14/03/1915 - São José dos Campos, 03/08/1990) foi compositora, pianista, regente e professora. Foi autora também de uma vasta produção literária, além de atuar em outras atividades, tais como radialista, arranjadora, etc.

Sua trajetória evidencia quatro momentos distintos, relacionados tanto à produção composicional como às atividades, filiações estéticas e artísticas por ela

\footnotetext{
7 Tais técnicas foram exploradas por compositores como Béla Bartók, que, entre outros, deu importantes contribuições pela pesquisa e emprego de modos folclóricos de seu país, Hungria, e regiões vizinhas.
} 
CANDIDO, M. et al. O atonalismo, a dodecafonia e a música nacional de Eunice Katunda em Variações sobre um tema popular e Quatro epígrafes

desempenhadas. Estes momentos foram designados pelos autores como Fase de Formação (até 1945), Fase Música Viva (1946-1950), Fase Nacionalista (19511968) e Fase Final (Após 1968).

No presente artigo abordaremos as duas fases iniciais da compositora, em que ela adota, respectivamente, uma escrita tradicional influenciada pelo movimento modernista, e uma outra que poderíamos identificar como internacionalista, pelo emprego da técnica dodecafônica. Essas fases serão aqui representadas pelas obras Variações sobre um tema popular (1943) e Quatro epígrafes (1948).

Um breve relato dessas duas primeiras fases se faz necessário para a compreensão do contexto de produção das obras e das atividades exercidas por Eunice em cada momento, bem como para refletir sobre em que medida esta produção dialoga com o artigo Atonalismo, dodecafonia e música nacional escrito pela compositora em 1952 e publicado pela revista Fundamentos.

\subsection{Fase de Formação}

Eunice Katunda iniciou seus estudos formais de piano ainda muito criança, aos cinco anos de idade. Ao longo dos anos aqui nomeados como Fase de Formação, passou pela orientação de diferentes professores(as) de piano e de matérias teórico-musicais, a citar Branca Bilhar, Oscar Guanabarino, Furio Franceschini, Marietta Lion e Camargo Guarnieri. Estas personalidades marcaram e influenciaram suas atividades como pianista e compositora, sendo inclusive possível encontrar textos escritos pela própria Eunice a respeito das aulas e seus reflexos, como, por exemplo, Riquezas da Tradição dedicado a Branca Bilhar e Furio Franceschini, meu primeiro Maestro di Música.

A musicista também iniciou suas apresentações públicas ainda quando criança, especificamente no período em que foi orientada por Branca Bilhar. Em 1925 participou de um concurso infantil e em 1927 realizou seu primeiro Recital de Piano, sendo que nestas duas primeiras performances públicas tocou peças de sua professora (Branca Bilhar) - Reminiscência e Bailado Indígena. Após a orientação de Branca, passou a ter aulas com Guanabarino e teve seu primeiro 
MUSICA THEORICA Revista da Associação Brasileira de Teoria e Análise Musical 2021, v. 6, n. 1, p. 100-132 - Journal of the Brazilian Society for Music

contato com um repertório de técnica pianística e com obras de Villa-Lobos, embora a contragosto de seu professor na época. ${ }^{8}$

A atividade de Eunice como pianista aumentou com o passar dos anos, as mudanças de professor(a) e até mesmo de cidade. Assim, após se casar com o matemático Omar Catunda (de quem herdou o sobrenome)' e já na cidade de São Paulo, iniciou seus estudos teóricos musicais com Furio Franceschini e passou a ter aulas de piano com Marietta Lion. A partir deste momento, suas apresentações de piano, até então baseadas principalmente no repertório musical tradicional europeu - com obras de Bach, Mozart, Beethoven e Chopin passaram a incluir mais peças de compositores brasileiros como, por exemplo, Fructuoso Viana e Villa-Lobos.

A inclusão das peças brasileiras em seu repertório acentuou-se ainda mais após começar a ter aulas de composição e piano com Camargo Guarnieri, em 1943. Este foi um período muito fértil para sua carreira de intérprete, pois contou com uma carta de recomendação de Heitor Villa-Lobos para realizar uma viagem à Argentina divulgando obras do compositor ${ }^{10}$.

A recomendação de Villa incidiu positivamente também sobre a carreira de Eunice Katunda como compositora, já que durante a citada turnê estreou sua primeira obra composta segundo a orientação de Guarnieri: Variações sobre um tema popular ${ }^{11}$. Sobre esta obra se falará mais adiante neste artigo.

É importante ressaltar as críticas positivas recebidas por Eunice pelos vários recitais realizados em Buenos Aires, dos quais destaca-se o Recital de

\footnotetext{
8 Eunice foi uma das únicas alunas de Guanabarino a tocar peças de Villa-Lobos, embora não tenha registro deste repertório em recitais da época. Aparentemente esta era uma iniciativa da própria pianista, já que seu professor apresentava críticas ao compositor e até mesmo o satirizava. Nas entrevistas concedidas por Eunice a Kater na década de 80, no qual os autores da presente pesquisa tiveram acesso integral, Eunice cita que Guanabarino chegou a lhe perguntar se ela conhecia a última peça de Villa-Lobos chamada "Maria limpa o piano", e que em seguida ele "passava a mão sobre o teclado [do instrumento] de qualquer jeito".

${ }_{9}^{9}$ Eunice se casou aos 19 anos, em 1934. Em 1968 se divorciou oficialmente e passou a assinar Katunda (com K) como nome artístico (Kater 2020, p. 31. 56).

10 Villa-Lobos, na época também diretor do Conservatório Nacional de Canto Orfeônico, considerava Eunice Katunda uma "excelente pianista que interpreta[va] com consciência e destacado temperamento" (Kater 2020, p. 39).

${ }^{11}$ Eunice compôs duas peças no período chamado como Fase de Formação: Variações sobre um tema popular (piano solo) e Lamento arabo (contralto e cordas). No entanto, a última peça citada foi extraviada.
} 
CANDIDO, M. et al. $\quad \mathrm{O}$ atonalismo, a dodecafonia e a música nacional de Eunice Katunda em Variações sobre um tema popular e Quatro epígrafes

Música Brasileira, em que interpretou peças de Branca Bilhar, Ernesto Nazareth, Camargo Guarnieri, Fructuoso Viana, Lorenzo Fernandes e Villa-Lobos ${ }^{12}$.

\subsection{Fase Música Viva}

A segunda fase composicional de Eunice, aqui chamada Música Viva, é estabelecida a partir do contato de Eunice Katunda com Hans-Joachim Koellreutter em 1946 no Rio de Janeiro. Sua relação com o professor, flautista, compositor e, na época, um dos principais signatários e idealizadores de um movimento de renovação da música brasileira denominado Música Viva, iniciou por meio de aulas de harmonia e criação musical.

O movimento Música Viva tinha como objetivo a divulgação e a promoção de obras musicais modernas da época e também peças do período tradicional pouco divulgadas no Brasil. Utilizava como ferramenta atividades de publicações, edições musicais, recitais comentados, programas radiofônicos, entre outros. Nesse contexto formou-se, em 1944, o grupo de compositores Música Viva, reunindo inicialmente Cláudio Santoro, César Guerra-Peixe e Koellreutter. O grupo foi ampliado em 1946, com o ingresso de Edino Krieger e da própria Eunice Katunda13.

Eunice participou de diversas atividades do movimento, seja como pianista, como compositora, radialista ou redatora de artigos nos boletins informativos. No programa radiofônico Música Viva realizado na rádio PRA-2, por exemplo, interpretou, muitas vezes em primeira audição brasileira, peças de compositores como Alban Berg, Pe. Manuel Rodrigues Coelho, Camargo Guarnieri, Paul Hindemith, Hans-Joachim Koellreutter, Edino Krieger, Juan

\footnotetext{
12 O Recital de Música Brasileira, realizado em 1944 durante a turnê de Eunice em Buenos Aires, teve o patrocínio do Instituto Lilbre de Cultura Integral e foi acompanhado por uma conferência do crítico musical argentino D. Gastón Talamon. Entre as peças apresentadas constaram Samba Sertanejo, de Branca Bilhar; Tanguinho, de Ernesto Nazareth; Valsa e Dança brasileira, de Camargo Guarnieri; Corta Jaca, de Fructuoso Viana; Cateretê, de Lorenzo Fernandes; e por fim as Cirandas Therezinha de Jesus, A pobre Cega, A'procura de uma agulha, Plantio Caboclo e Miudinho, do compositor Villa-Lobos.

${ }^{13}$ Uma discussão aprofundada sobre a constituição, atuação e dissolução do grupo Música Viva (1944-1950) foi realizada por Candido (2017) em sua pesquisa de mestrado.
} 
MUSICA THEORICA Revista da Associação Brasileira de Teoria e Análise Musical 2021, v. 6, n. 1, p. 100-132 - Journal of the Brazilian Society for Music

Carlos Paz, César Guerra-Peixe, Henry Purcell, Camillo Togni e Heitor VillaLobos, além de obras de seu próprio catálogo ${ }^{14}$.

Realizou também recitais nacionais e internacionais enquanto esteve ligada ao movimento, como a apresentação solo no Recital Autores de Vanguarda e em diversas audições coletivas de Música Contemporânea promovidas pelo Música Viva ${ }^{15}$.

Apresentou-se no exterior em decorrência de uma viagem para a Europa em 1948, na qual teve a companhia de Koellreutter e de outros colegas para participar do Curso Internacional de Regência ministrado pelo professor Hermann Scherchen na Bienal de Veneza. Nessa viagem, que terminou sendo prolongada por quase um ano, Eunice obteve grande destaque como intérprete oficial do grupo na Itália e na Suíça ${ }^{16}$.

Já em relação à composição, Eunice compôs sete obras enquanto esteve ligada ao Música Viva - Negrinho do Pastoreio (1946), Cantos à morte (1946), Sonatina (1946), Salmo 82 (1947), Quatro epígrafes (1948), Lirici greci (1949) e Quinteto Schoenberg (1949) - sendo possível identificar o emprego da técnica dodecafônica ${ }^{17}$ em algumas dessas composições como, por exemplo, em Quatro Epígrafes.

O uso da técnica dodecafônica, bem como o posicionamento político de vários(as) integrantes do grupo Música Viva18, tornou-se praticamente a marca pela qual o grupo ficou registrado na história da música brasileira.

\footnotetext{
${ }^{14}$ Sobre compositores e obras interpretadas nos programas radiofônicos Música Viva, cf. Kater 2001b, p. 289-301.

${ }^{15}$ Digno de nota é o evento realizado na União Cultural Brasil-Estados Unidos de São Paulo, em que a pianista interpretou obras de Cláudio Santoro, Guerra-Peixe, Koellreutter e de autoria própria.

${ }^{16}$ Eunice Katunda estreou, entre outros, o Ludus tonalis (1942) de Paul Hindemith na Itália e no I Congresso Internacional de Compositores Dodecafônicos, realizado em Lugano.

${ }^{17}$ A técnica dodecafônica, ou dodecafonismo, foi um método criado por Arnold Schoenberg para compor usando os doze sons da coleção cromática a partir de séries ordenadas sem a repetição de qualquer elemento. A construção melódica e harmônica do discurso se dá através de recursos do contraponto, tais como retrógrado, inversão e retrógrado da inversão da série originalmente proposta.

${ }^{18}$ Eunice Katunda, Esther Scliar, Claudio Santoro, Cesar Guerra-Peixe, entre outros(as), se filiaram ao partido Comunista entre a primeira e a segunda metade do século XX.
} 
CANDIDO, M. et al. $\quad \mathrm{O}$ atonalismo, a dodecafonia e a música nacional de Eunice Katunda em Variações sobre um tema popular e Quatro epígrafes

\section{Atonalismo, dodecafonia e música nacional}

A discussão que motivou Eunice Katunda a escrever e publicar, em 1952, o texto Atonalismo, dodecafonia e música nacional na revista Fundamentos, partiu de uma carta de Claudio Santoro sobre os riscos identificados no uso da técnica dodecafônica para as novas gerações de músicos no Brasil de 1948. Santoro, que em 1941 já assumia uma postura crítica em relação à construção de uma "escola de composição brasileira" a partir do que considerava um simples "aproveitamento temático" do folclore nacional - propondo o estudo deste material baseado "em sua origem, não histórica, mas técnica" (Santoro p. 7, apud Mendes 2009, p. 21) - se interessou pelo método de escrever com os 12 sons da escala (ou coleção) cromática em torno de 1940, quando foi estudar com o criador do Música Viva. Mendes (ibid., p. 24) conta que foi por intermédio de Koellreutter que "Santoro pôde lançar mão do rigor lógico do sistema dodecafônico para organizar e justificar a linguagem marcadamente cromática que vinha praticando de forma instintiva até então". Entretanto, o compositor mudaria radicalmente de opinião após frequentar o II Congresso de Compositores Progressistas de Praga ${ }^{19}$, onde se pregou o Realismo Socialista. Tal estética, se pudermos chamar assim, defendia uma

educação musical fundamentada nas bases populares e folclóricas de cada região, e estudo destas mesmas manifestações musicais para subsidiar o material utilizado na composição, de forma a construir uma música com identidade nacional e "positiva", capaz de penetrar nas camadas mais populares da sociedade (Hartmann 2010, p. 462).

De personalidade apaixonada e dada a posicionamentos radicais, Eunice a princípio respondeu a Santoro com o texto Problemas musicais contemporâneos, datado de 1950 e publicado na Folha de S. Paulo, onde defendeu a ideia de que:

Como toda técnica, o atonalismo só tem valor por servir a uma necessidade de expressão artística. A dodecafonia resulta do atonalismo. O atonalismo só teve um período muito restrito como atitude estética. Também não foi Schoenberg quem o inventou. Existiu de fato em toda música que não adotou o sistema absolutista de predominância da Tônica. (Katunda 1950, p. 1).

De fato, a compositora falou com propriedade sobre o uso do atonalismo como, simplesmente, uma alternativa ao sistema rígido de predominância da

\footnotetext{
${ }^{19}$ Kater se refere ao evento frequentado por Santoro em Praga como II Congresso Internacional de Compositores e Críticos Musicais (cf. Kater 2020, p. 66).
} 
MUSICA THEORICA Revista da Associação Brasileira de Teoria e Análise Musical 2021, v. 6, n. 1, p. 100-132 - Journal of the Brazilian Society for Music

tônica. Em suas Variações sobre um tema popular, Eunice já trabalhara livremente com coleções referenciais outras que não as diatônicas adotadas pelo tonalismo como maior e menor, como, por exemplo, a de tons inteiros, a cromática e as demais diatônicas que coincidem com modos gregos e/ou populares de outros países.

Em Problemas musicais contemporâneos, ela diria: “É atonal toda música que escapou de um modo ou de outro à influência da civilização musical ocidental, apesar de se manter ainda viva ao lado da outra, exercendo sua função social de arte mesmo dentro daquela civilização". Ela chega a citar compositores que, como ela mesma e, provavelmente, Villa-Lobos - cuja influência é notória em suas obras, como se verá mais adiante - enveredaram pelo atonalismo como maneira de atingir uma maior liberdade de expressão musical:

A atitude estética "atonalismo" correspondeu a um período de rebelião contra as normas harmônicas, contra o academicismo harmônico que insistia em se arvorar em Lei quando já estava praticamente morto, já que a maior parte das convenções de harmonia não passavam de anacronismos que todos os compositores vinham sistematicamente contrariando no percurso da evolução, até eliminá-los quase por completo como necessidade (Katunda 1950, p. 2. Aspas e grifos da compositora).

A superação das regras consideradas ultrapassadas pela musicista pelo uso da técnica baseada na organização das alturas a partir do raciocínio serial, como foi o dodecafonismo, é explicada por Eunice no texto:

Foi esse o período anárquico que precedeu a toda restruturação da técnica de composição musical. Com esse período acabou-se o período dos absolutismos tais como o absolutismo da consonância ou o da dissonância. [...] O essencial permaneceu, porém, depois de descoberto por Schoenberg um simples método novo de composição, de técnica, baseado esse não sobre princípios acadêmicos, mas sobre as leis fundamentais que presidem a criação da obra de arte de qualquer tempo. Essa técnica veio servir a uma necessidade e como técnica jamais poderia constituir um fim em si (ibid., p. 3).

Esses pensamentos da compositora são essenciais para compreender sua obra, seja nas duas fases discutidas nesse artigo ou nas duas posteriores. Eunice Katunda jamais se deixou amarrar por absolutismos estéticos de qualquer espécie, embora política e socialmente tenha oscilado com veemência entre ideias muitas vezes contraditórias. 
CANDIDO, M. et al. $\quad \mathrm{O}$ atonalismo, a dodecafonia e a música nacional de Eunice Katunda em Variações sobre um tema popular e Quatro epígrafes

Sua meta parece ter sido sempre a criação daquela música moderna e nacional mencionada por Barros (2013) e citada na introdução deste texto. Para isso, tanto o atonalismo modal descrito por Coelho de Souza (2009), como o dodecafonismo, visto pela compositora como um "produto do processo dialético da evolução musical", responderiam a emergências da arte musical. Em suas palavras: "Emergência no sentido filosófico do termo" ${ }^{20}$ (ibid.).

Não obstante, a compositora chega a negar o uso da técnica dodecafonica - e a própria noção de atonalismo como ruptura com a opressão do sistema tonal, professada por ela anteriormente - em sua publicação Atonalismo, dodecafonia e música nacional. Tal pronunciamento pode ter sido movido por um sentimento de revolta por se julgar enganada por forças aparentemente desinteressadas. Como disse Kater (2020, p. 157),

Este pode ser considerado um "documento-manifesto", no qual Eunice enfatiza a ruptura com a linha que vinha sendo imprimida pelo Música Viva e assume confronto direto com H. J. Koellreutter. É, em certo sentido, uma versão mais fundamentada e consistente dos tópicos abordados por C. Guarnieri em sua famosa Carta aberta aos músicos e críticos do Brasil ${ }^{21}$.

Em seu artigo de 1952, Eunice diz que desde a conferência dada por Santoro para estudantes da Faculdade de Arquitetura e Urbanismo, vinha sendo questionada sobre se era possível "fazer música atonal, ou dodecafônica, de caráter nacional" (Katunda apud Kater 2020, p. 157). Ao que, desta vez, ela respondeu um sonoro "NÃO", com letras maiúsculas, argumentando que tal ideia vinha sendo disseminada “à boa fé de nossa juventude por elementos que buscam exercer sobre ela uma influência que só pode ser nociva e confusionista" (ibid.).

Ao contrário do que havia dito antes, a compositora afirma que

\footnotetext{
${ }^{20}$ Neste sentido vale ressaltar a influência dos ensinamentos de Koellreutter aos integrantes do Grupo Música Viva, como atesta Ana Cláudia Assis (2010, p. 59) em relação a Guerra-Peixe: O papel de Koellreutter na trajetória de Guerra-Peixe não se restringiu ao ensino da técnica dodecafônica, antes, teve um contingente filosófico representativo".

${ }^{21}$ A Carta aberta aos músicos e críticos do Brasil foi publicada por Mozart Camargo Guarnieri em 17 de dezembro de 1950 no jornal O Estado de São Paulo. Seu conteúdo alertava os jovens "para os perigos da difusão de ideias alienantes e anti-nacionais, conclamando a todos para que valorizassem as raízes e a música popular brasileira". (Zani; Monteiro da Silva; Candido 2019, p. 122).
} 
MUSICA THEORICA Revista da Associação Brasileira de Teoria e Análise Musical 2021, v. 6, n. 1, p. 100-132 - Journal of the Brazilian Society for Music

A palavra atonalismo, cujo único sentido é o de uma simples atitude negativista, tornou-se um verdadeiro centro de confusão terminológica, chegando a assumir a força de um dogma. Passou a ser confundida com os termos "modernismo", "inovação" e até, para muitos, chegou a ser sinônimo de "música contemporânea" (Katunda apud Kater 2020, p. 160. Aspas da compositora).

Sobre o dodecafonismo em si, ela diria que o fato de que nele elementos como som, ritmo, melodia, timbre e forma seriam, de certa maneira, "valorizados cada um de per-si, em detrimento da unidade do conjunto deles", tornaria a música desintegrada, "desumanizada, alucinante, a ponto de adquirir, para alguns, a capacidade de abstração que chega a transformá-la, de arte sonora, em arte puramente gráfica" (ibid.).

E termina comprovando a mágoa que a levou a negar seu próprio entendimento estético e filosófico acerca da composição musical enquanto expressão artística livre e independente - ao menos idealmente - dos interesses políticos de cada tempo e lugar:

Quem embarque nesse canto de sereia, de fazer música nacional por meio do atonalismo e da técnica dodecafônica, incorrerá no mesmo erro em que já incorreu a autora do presente artigo: o de pecar por inconsciência e por excesso de ingenuidade, que é também uma forma de ignorância (ibid., p. $171)$.

\section{Análise musical}

A fim de exemplificar musicalmente o posicionamento estético assumido por Eunice Katunda em suas duas primeiras fases, Fase de Formação e Fase Música Viva, segue-se uma análise sucinta das peças para piano Variações sobre um tema popular e Quatro epígrafes. É possível notar a intenção da compositora de romper as barreiras do tonalismo já na primeira obra composta sob a orientação de Guarnieri, baseada no tema popular Garibaldi, o que se concretiza formalmente na adoção da técnica dodecafônica para as peças compostas no período em que estudou e trabalhou com Koellreutter no Música Viva, como Quatro epígrafes. 
CANDIDO, M. et al. $\quad$ O atonalismo, a dodecafonia e a música nacional de Eunice Katunda em Variações sobre um tema popular e Quatro epígrafes

\subsection{Variações sobre um tema popular}

Além de ser a primeira obra composicional de Eunice como aluna de Camargo Guarnieri, Variações sobre um tema popular é a única obra disponível da aqui chamada Fase de Formação. A peça, com duração de cerca de 10 minutos, é apresentada sob a forma de tema e variação, compreendendo 13 variações do tema folclórico "Garibaldi".

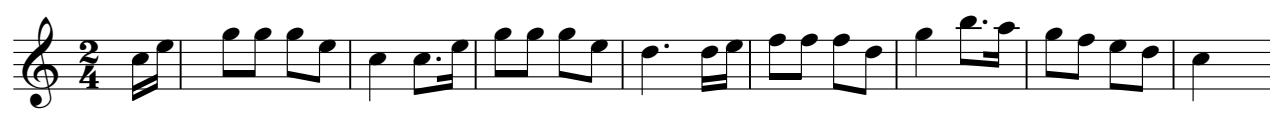

Exemplo 1: Tema "Garibaldi" empregado em Variações sobre um tema popular.

Apesar de empregar uma forma musical neoclássica e um material de caráter nacionalista, a obra se desenvolve por meio de um atonalismo que se assemelha ao que Coelho de Souza denominou modal, conforme citado na introdução deste artigo. De acordo com o autor, o volume de "saturação cromática e encadeamentos harmônicos não funcionais" tornaram quase inevitável a substituição do termo atonalismo como usado na música serial "pelos novos fundamentos do atonalismo enunciados por Schoenberg" (Coelho de Souza 2009, p. 139).

Observa-se também que a compositora combina esta escrita com texturas contrapontísticas, melodia acompanhada e/ou colagem de materiais ao longo do ciclo. De acordo com Coelho de Souza, esta vertente musical tem como origem a escola franco-russa, que buscou empregar "materiais modais inspirados em fontes populares ou exóticas" em reação à corrente germânica e a sua subjetividade expressionista. Além disso, o autor também cita que:

A sistematização de estruturas modais, superpostas e justapostas, tal como empregada por esses compositores [Debussy, Stravinsky e Bartók], acabou conduzindo a resultados igualmente despojados do sentido da tonalidade, não só quanto aos encadeamentos - o que seria previsível em se tratando de música modal - mas também na complexidade dissonante dos conglomerados, uma vez que a independência contrapontística das linhas modais sobrepostas produziu sucessões de dissonâncias tão formidáveis quanto as da música serial. Para essa escola bastou, portanto, recuperar e ampliar práticas modais esquecidas no tempo para eliminar um dos pilares da música tonal - o encadeamento funcional dos acordes - criando uma das muitas poéticas possíveis da música atonal (ibid., p. 139-140). 
MUSICA THEORICA Revista da Associação Brasileira de Teoria e Análise Musical 2021,

v. 6, n. 1, p. 100-132 - Journal of the Brazilian Society for Music

O uso de um atonalismo baseado em modos, mas que se distinguia da música modal folclórica anterior à tonalidade - como apontou Coelho de Souza (ibid, p. 141) - parece ter servido à Eunice Katunda para dar a uma música de caráter nacionalista um sopro de modernidade. Como ela disse no texto que dá nome a esse artigo, "toda música nacional, nos países da civilização ocidental de cuja tradição musical descendemos, é caracteristicamente tonal e até modal, como é a nossa" (Katunda apud Kater 2020, p. 168. Grifo da autora).

$\mathrm{O}$ uso de modos/coleções na música brasileira deste período não é antagônico à estética nacionalista à qual a compositora se vinculava em sua Fase de Formação. Ernesto Hartmann elenca, como elementos ou tópicas ${ }^{22}$ referentes ao nacionalismo,

[...] esquemas rítmicos e uso eventual de coleções escalares modais ou pentatônicas, frases não quadradas e irregulares, emprego de agregações harmônicas resultantes de combinações pouco usuais de notas ornamentais que destacam a dissonância (geralmente pela utilização de falsas relações) e o uso sistemático de sequências cromáticas descendentes (Hartmann 2017, p. 9).

Este idioma atonal modal é utilizado ao longo de toda a peça de Eunice. Como exemplo, segue o início do Tema de Variações sobre um tema popular, no qual há uma sobreposição da coleção diatônica que coincide com o modo Do Jônio ${ }^{23}$, empregada na melodia, sobre a coleção cromática, usada no acompanhamento. Esse acompanhamento é realizado por meio de acordes com aberturas intervalares crescentes e decrescentes, procedimento também presente em obras de Villa-Lobos - como será mostrado mais adiante.

22 Tópicas podem ser definidas como figuras de retórica do vocabulário musical. No caso da música brasileira, Acácio Piedade $(2007$, p. 5) atesta que "uma retórica se faz presente articulando tópicas que colocam em jogo identidades e referências culturais que constroem um universo cultural entendido como brasileiro", como "tópicas afro" (presente nos batuques, lundus, jongos, etc.), "tópicas caipiras" (duetos em terças e sextas paralelas; ponteios da viola caipira), "tropical" (remetendo-se às florestas e à exuberância tropical), entre outras.

${ }^{23}$ Nos referimos ao material utilizado como coleção - e não como modo - pelo uso distinto que Eunice Katunda faz desse material, como foi explicado anteriormente na referência ao atonalismo modal. Entretanto, para melhor localizar determinadas coleções diatônicas, fazemos referência aos modos a que elas se assemelham, chamando-as de coleções/modos. 
CANDIDO, M. et al. $\quad \mathrm{O}$ atonalismo, a dodecafonia e a música nacional de Eunice Katunda em Variações sobre um tema popular e Quatro epígrafes

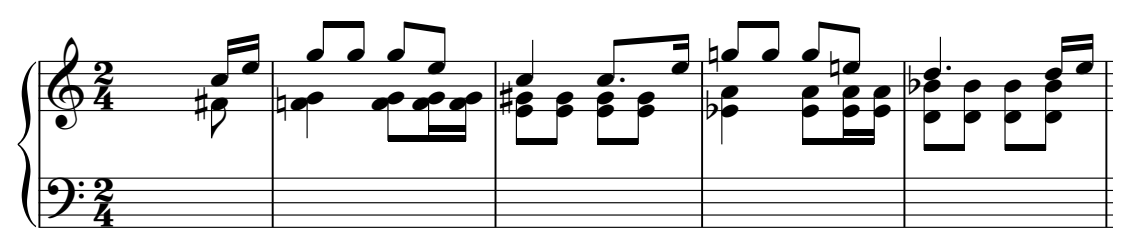

Exemplo 2: Tema de Variações sobre um tema popular: melodia na coleção/modo de Dó jônio sobre acompanhamento cromático em acordes com aberturas intervalares crescentes (c. 1-4).

Da mesma maneira, observa-se a sobreposição de coleções nas Variações 3 e 4. A Variação 3 (Ex. 3) segue o modelo do tema, somente usando a coleção/modo de Dó\# Jônio (em vez de Dó), sobre a coleção cromática. Já na Variação 4 (Ex. 4), a melodia e os acordes apresentados nos tempos fortes dos compassos (às vezes no $1^{\text {o }}$, às vezes no $1^{\circ}$ e no $2^{\circ}$ ), utilizam a coleção/modo de Réb Jônio - enarmônico do Dó\# -, enquanto que o restante do acompanhamento baseia-se na coleção cromática, também em aberturas intervalares crescentes e decrescentes.

$\mathrm{O}$ uso de armaduras de clave, e mesmo de acordes que remetem à escrita tonal - como Réb M (T) e Solb m (s) na Variação 4 (Ex. 4) - pode demonstrar o desejo da compositora de transitar livremente por todas as tendências e linguagens disponíveis, ou, como observou Maria Lucia Pascoal (1989, p. 253) a respeito da escrita de Debussy em seus Preludios, o fato de o compositor "ainda escrever as armaduras como na convenção tonal [...], parece ser somente por uma economia de escrita, uma vez que o resultado sonoro não é tonal". No caso de Debussy, Pascoal complementa dizendo que ele "consegue se libertar da tonalidade como sistema de relações entre acordes, resoluções, consonânciasdissonâncias" (ibid).

Entendemos que isso ocorre também na obra da compositora Eunice Katunda aqui analisada.

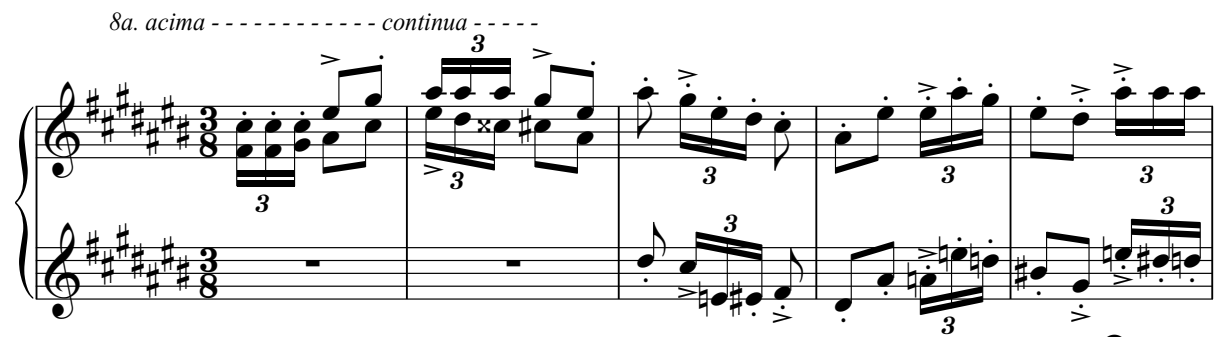

Exemplo 3: Sobreposição de coleção/modo Dó\# Jônio à coleção cromática na Variação 3 de Variações sobre um tema popular (c. 1-5). 


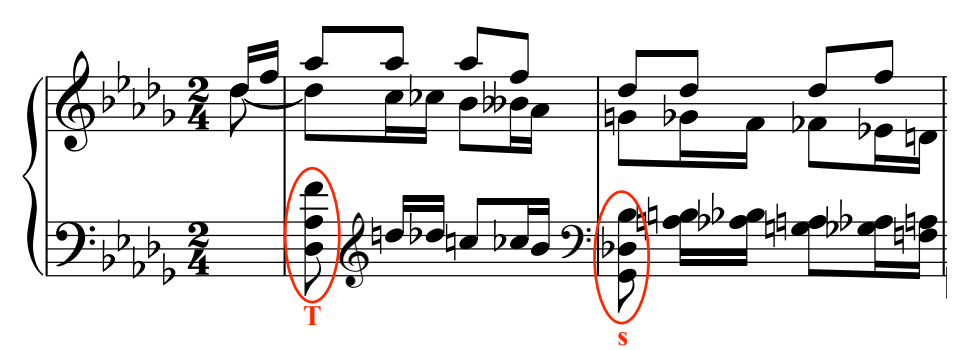

Exemplo 4: Variação 4 (c. 1-2): melodia e acordes nos tempos fortes usam coleção/modo de Réb Jônio com acordes que remetem a funções tonais (T e s), enquanto o restante do acompanhamento usa coleção cromática.

Também são observadas polirritmias ao longo das Variações, decorrentes da sobreposição de camadas texturais independentes. Na Variação 2, esta polirritmia pode ser observada por meio da sobreposição de três camadas, sendo a primeira voz realizada por semicolcheias, a segunda por tercinas de semínimas e a terceira voz em mínimas, conforme as Exs. 5 e 6.
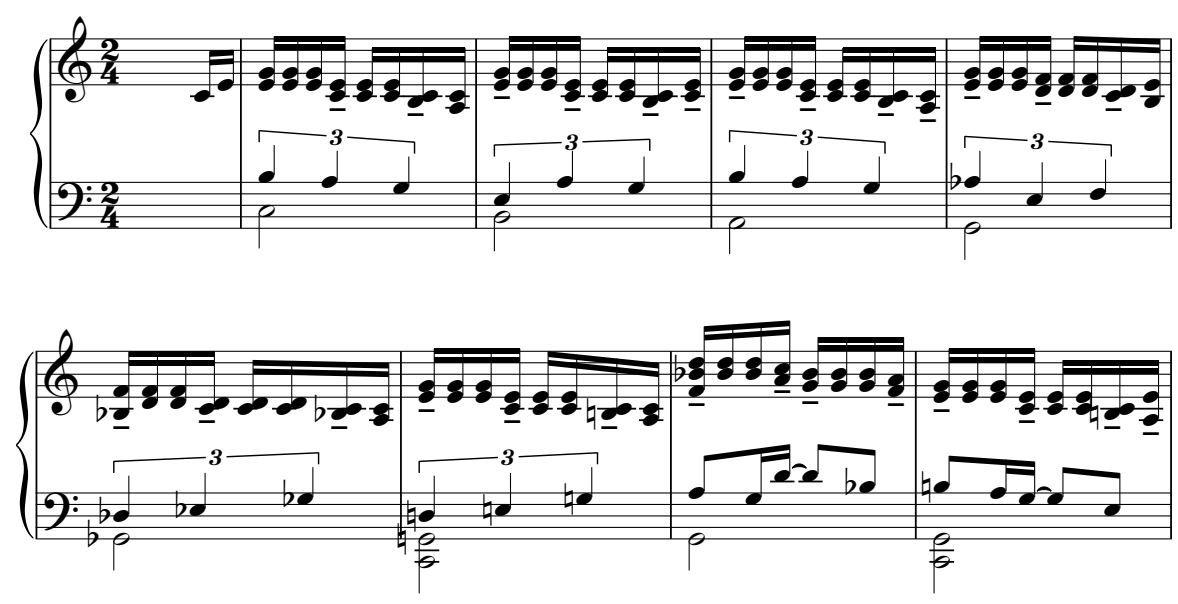

Exemplo 5: Sobreposição de três camadas texturais independentes na Variação 2 de Variações sobre um tema popular (c. 1-8).

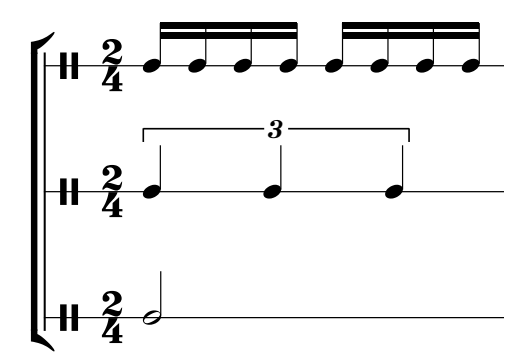

Exemplo 6: Polirritmia entre as três camadas texturais da Variação 2. 
CANDIDO, M. et al. $\quad \mathrm{O}$ atonalismo, a dodecafonia e a música nacional de Eunice Katunda em Variações sobre um tema popular e Quatro epígrafes

Além do tratamento atonal modal observado ao longo de toda a peça, verifica-se a presença de texturas contrapontísticas em Variações sobre um tema popular. Como exemplo, observa-se o emprego de uma textura em 3 vozes na Variação 1, sendo esta realizada por meio de um cânone do tema nas vozes extremas da peça.

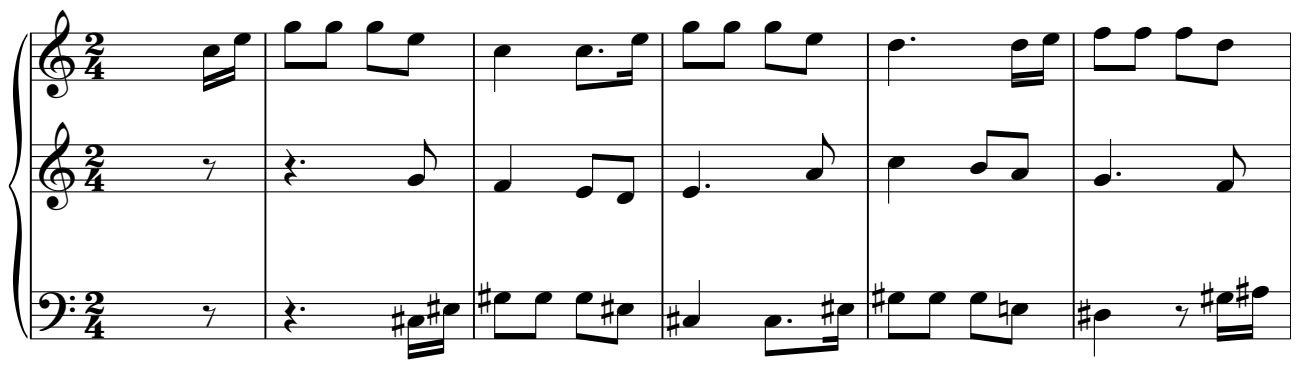

Exemplo 7: Emprego de cânone do tema principal apresentado no pentagrama superior e no pentagrama inferior da Variação 1. (c. 1-5).

O uso do contraponto denota a influência do professor Camargo Guarnieri nessa obra da compositora, já que, de acordo com Lutero Rodrigues (2015, p. 2), “é provável que a característica mais marcante e pessoal da linguagem musical do compositor [Guarnieri], presente em toda a sua obra, seja o predomínio da textura polifônica".

O emprego destas texturas contrapontísticas também pode ser visualizado em outras variações do ciclo, como na sexta, oitava, décima segunda e última variação. Verifica-se nestas variações o uso de polifonia a 4 vozes, tema sobreposto a outras camadas texturais, entre outros procedimentos.

O contraponto em cânone também aparece no aspecto rítmico deste ciclo de Variações. Fazendo uso de ostinatos ${ }^{24}$ de tipo modernista, ${ }^{25}$ Eunice apresenta um motivo rítmico de 2 compassos em cânone entre a melodia e o acompanhamento em todos os compassos do Tema que abre a obra, como

24 "Como palavra italiana, ostinato faz plural ostinati; entretanto, de acordo com o uso corrente em nosso meio musical, e evitando pedantismos, empregamos o plural aportuguesado ostinatos" (Seixas 2006, p. 5).

${ }^{25}$ Seixas chama de ostinato modernista aquele que, diferentemente do tradicional usado nos séculos XVII a XIX, não prevê um desenvolvimento que acompanha a melodia ou as vozes superiores. Em vez disso, o ostinato das primeiras décadas do século XX é estático, permanecendo sobre as mesmas alturas em vez de explorar novos acordes e tons, como anteriormente (ibid.). 
MUSICA THEORICA Revista da Associação Brasileira de Teoria e Análise Musical 2021, v. 6, n. 1, p. 100-132 - Journal of the Brazilian Society for Music

mostram as Exs. 8 e 9. Este motivo rítmico aparece por vezes variado por meio de pontos de aumento, na voz superior, ou pelo desdobramento da semínima em duas colcheias, na voz inferior, como mostra a Ex. 9.
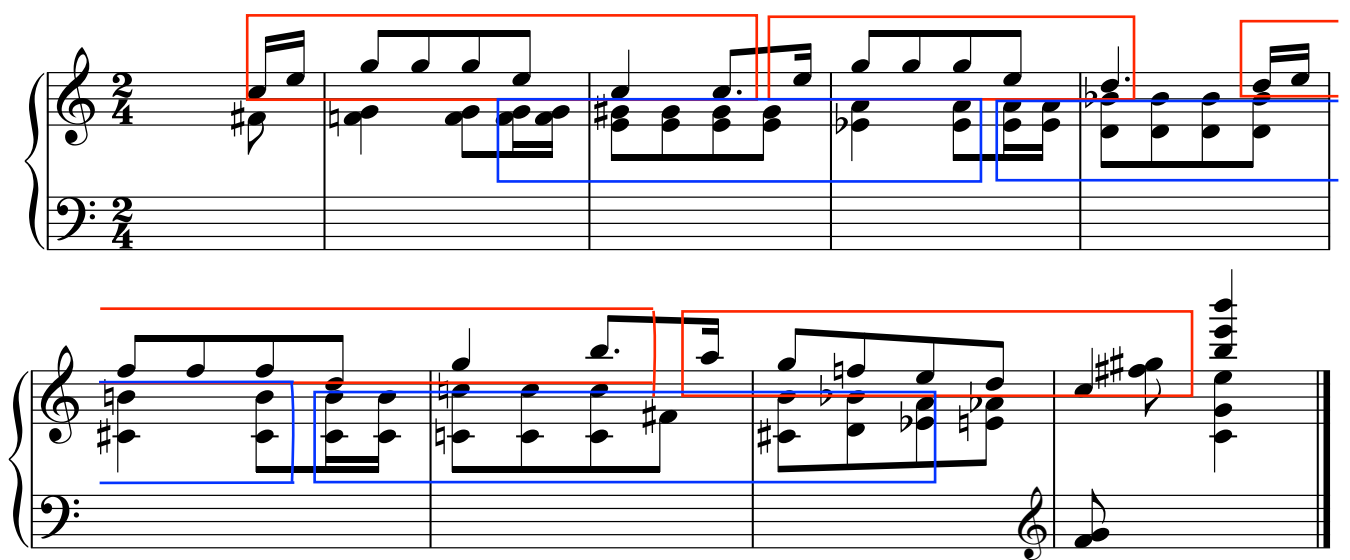

Exemplo 8: Ostinato rítmico presente nos dois planos em cânone na Variação 1 (c. 1 $8)$.

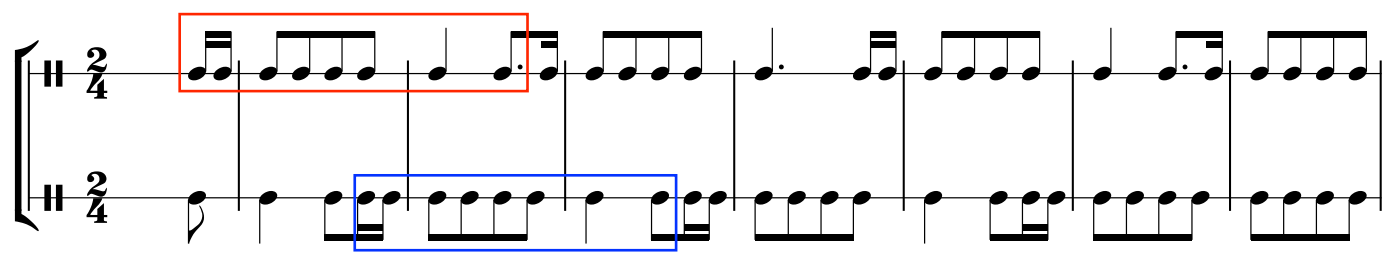

Exemplo 9: Ostinato rítmico presente nos dois planos em cânone na Variação 1 (c. 1-7).

O ostinato, bem como o modelo de díades em intervalos crescentes e decrescentes do Tema, é também lembrado na última variação, porém em amplitudes exacerbadas e repetido a cada compasso, com ares de gran finale (Ex. 10).

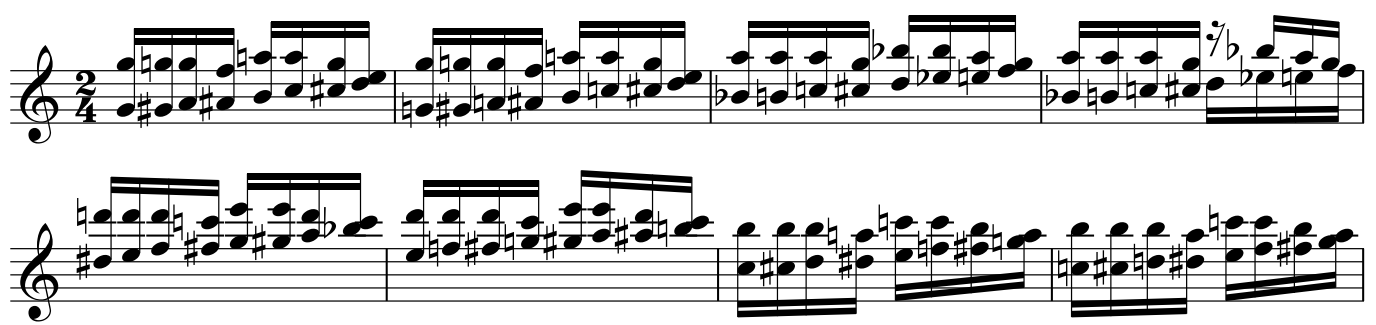

Exemplo 10: Ostinato rítmico presente no pentagrama superior da Variação Final (c. 1$8)$. 
CANDIDO, M. et al. $\quad \mathrm{O}$ atonalismo, a dodecafonia e a música nacional de Eunice Katunda em Variações sobre um tema popular e Quatro epígrafes

É interessante notar o emprego do acorde aumentado de Dó em forma de arpejo no início da Variação 5, apontando o uso da coleção de tons inteiros pela compositora. Apresentando a melodia no plano inferior e acompanhamento em acordes arpejados no superior, essa coleção aparece na base Dó entre os c. 1 e 3, 7 e 8 (com anacruses), e na base Dó\# nos c. 4 a 6 (1ํompo).

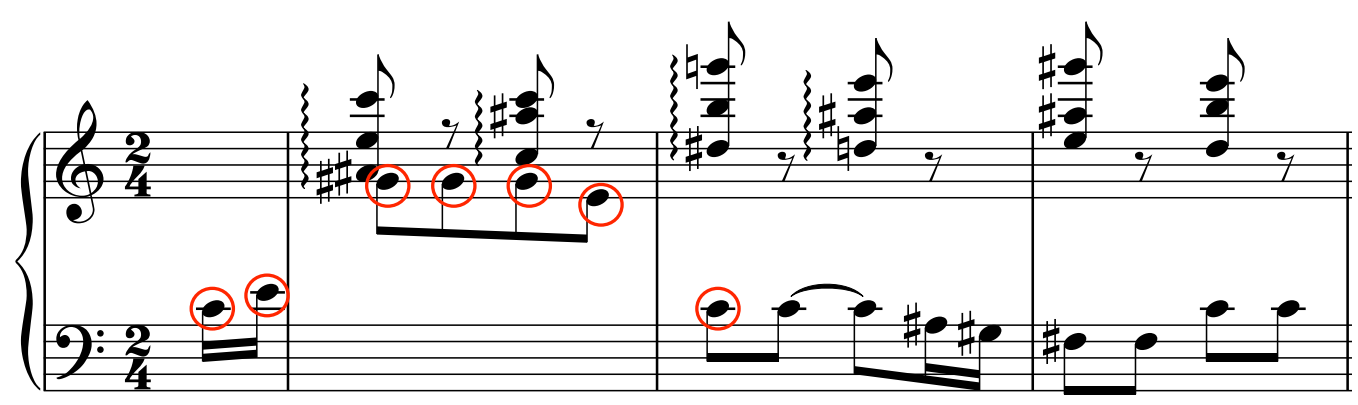

Exemplo 11: Acorde aumentado de Dó aponta coleção de tons inteiros na Variação 5 (c. $1-3)$.

Assim como a Variação 5, outras variações também apresentam o procedimento de melodia acompanhada. A sétima, a nona e a décima variações, por exemplo, trazem o tema folclórico muito claro e definido em uma das vozes, apesar de eventuais alterações rítmicas.

Como exemplo de alteração rítmica na melodia do Tema tem-se a Variação 9. Além de não utilizar a anacruse habitual, o emprego de semínima pontuada seguida de colcheia denota que a compositora usou a técnica da aumentação, conforme mostram os Exs. 12 e 13. Isso faz com que a Variação fique com o dobro de compassos do Tema principal: 16 compassos no lugar de 8.

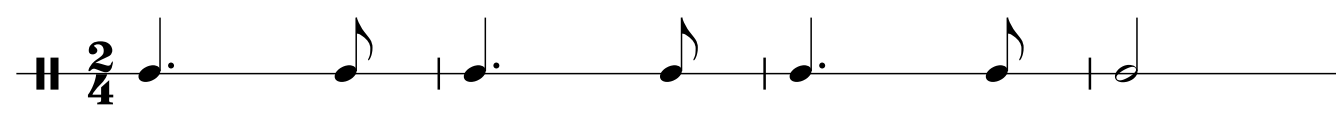

Exemplo 12: Ritmo empregado na voz mais aguda da Variação 9, também à maneira de ostinato (c. 1-5). 


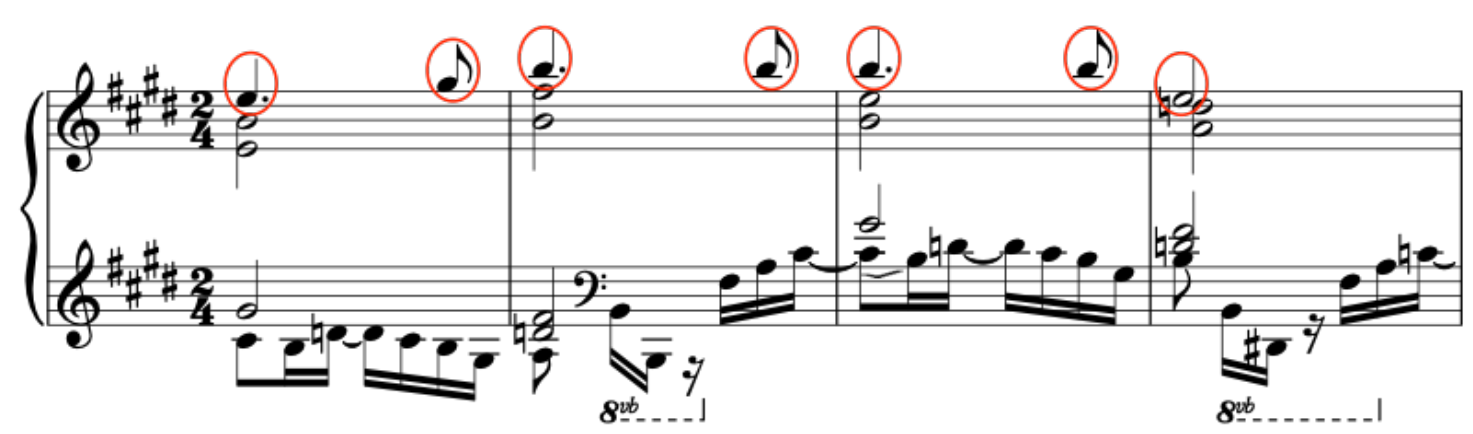

Exemplo 13: Variação 9 (c. 1-4).

Nota-se o uso de um ostinato sincopado na linha mais grave desta variação, como mostra o Ex. 14:

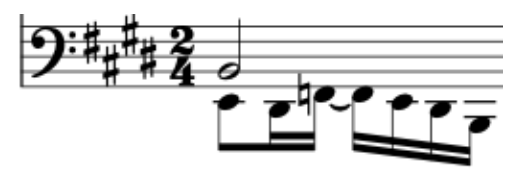

Exemplo 14: Ostinato sincopado na linha inferior da Variação 9.

Os procedimentos empregados por Eunice Katunda testemunham sua sintonia com o clima nacionalista - e, ao mesmo tempo, rebelde - da primeira metade do século XX. Como disse Assis (2010, p. 59), naquele momento "os jovens músicos brasileiros [...] encontravam-se desestimulados em seguir a estética nacionalista", e buscavam, como nas primeiras décadas do século com Mário de Andrade, refletir sobre "o papel do músico e da linguagem musical diante dos problemas político-sociais contemporâneos".

A título de mostrar esse diálogo entre a composição de Eunice Katunda nessa sua Fase de Formação com compositores como Villa-Lobos, seguem alguns exemplos de obras interpretadas por ela enquanto pianista, que com certeza influenciaram suas escolhas no âmbito da composiçãoe.

Para começar, temos o próprio tema Garibaldi foi a missa, em que a pianista baseia suas Variações sobre um tema popular. Este tema é verificado em duas peças de Villa: Garibaldi foi a missa (1912 - n. 5 da coleção Brinquedo de roda) e Garibaldi

\footnotetext{
${ }^{26}$ Sabendo que a compositora-pianista apresentara obras de Heitor Villa-Lobos na Audição realizada para o compositor em 1943 na Escola de Música de Villa-Lobos, assim como na citada turnê pela Argentina - onde interpretou as Cirandas Therezinha de Jesus, Pobre cega, À procura de uma agulha e as peças Plantio caboclo e Miudinho -, é possível identificar nestas Variações a influência do compositor modernista, além da de seu professor à época - Camargo Guarnieri.
} 
CANDIDO, M. et al. $\quad \mathrm{O}$ atonalismo, a dodecafonia e a música nacional de Eunice Katunda em Variações sobre um tema popular e Quatro epígrafes

foi a missa (1932 - 4 ${ }^{\underline{a}}$ peça do Álbum n. 3 do Guia Prático), conforme exemplos a seguir.
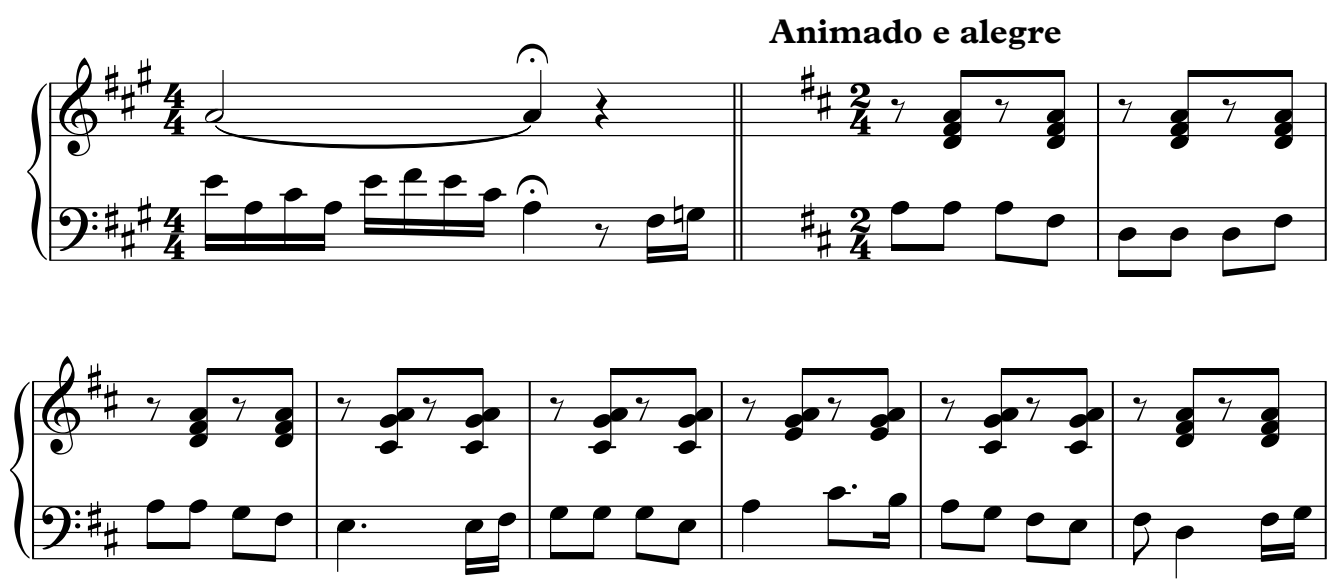

Exemplo 15: Garibaldi foi à missa (n. 5 da coleção Brinquedo de roda), de Villa-Lobos (c. 816). Melodia do tema é apresentada no pentagrama inferior.

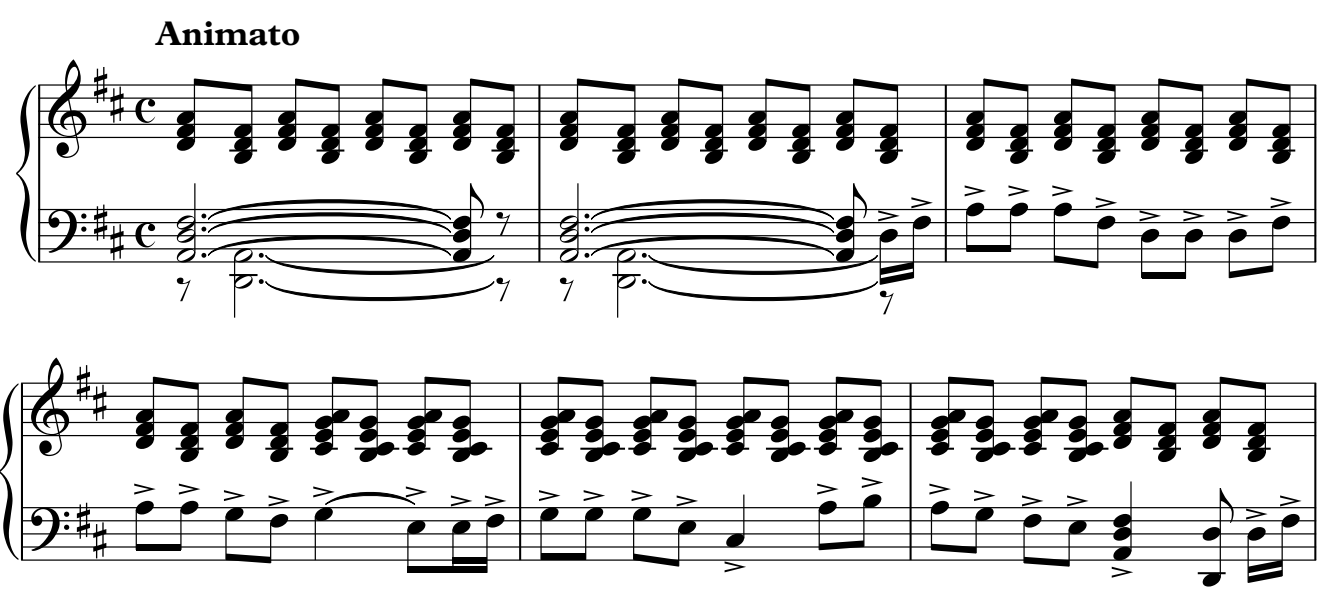

Exemplo 16: Garibaldi foi à missa (4⿳亠丷⿵冂⿱⺊口灬 peça do Álbum n. 3 do Guia Prático), de VillaLobos (c. 1-6). Melodia do tema é apresentada no pentagrama inferior.

O uso de díades em intervalos crescentes e decrescentes, bem como de acentos deslocados, ostinatos e exploração dos registros extremos do piano, além do atonalismo modal, também ecoa algumas obras para piano de Villa, como $O$ Cravo brigou com a rosa (Ciranda n. 4) e À procura de uma agulha (Ciranda n. 13). 

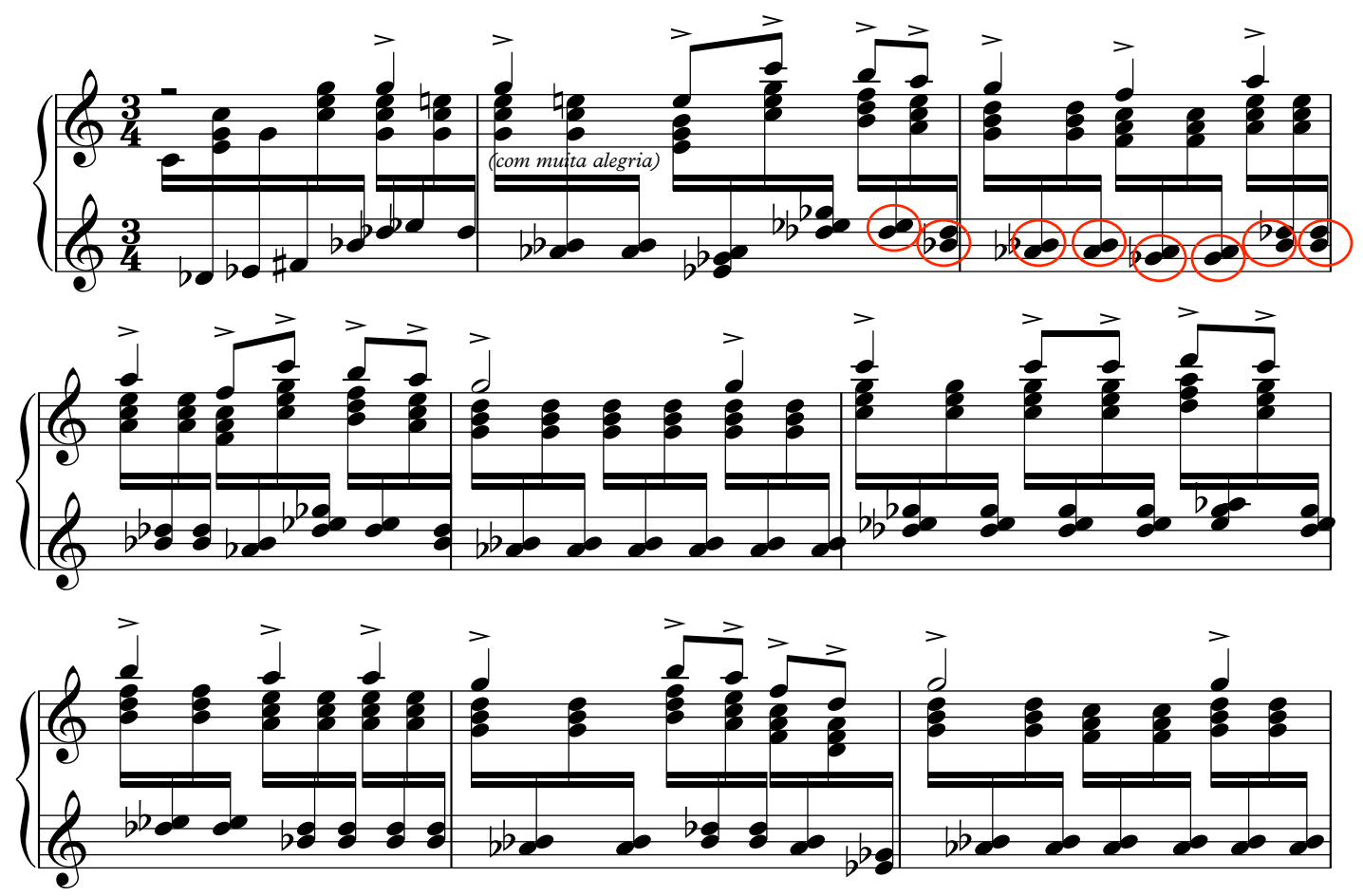

Exemplo 17: O Cravo brigou com a rosa (Ciranda n. 4), de Villa-Lobos. Melodia apresenta coleção/modo de Dó jônio, enquanto acompanhamento inclui díades com aberturas intervalares cromáticas crescentes e decrescentes (c. 4-12).
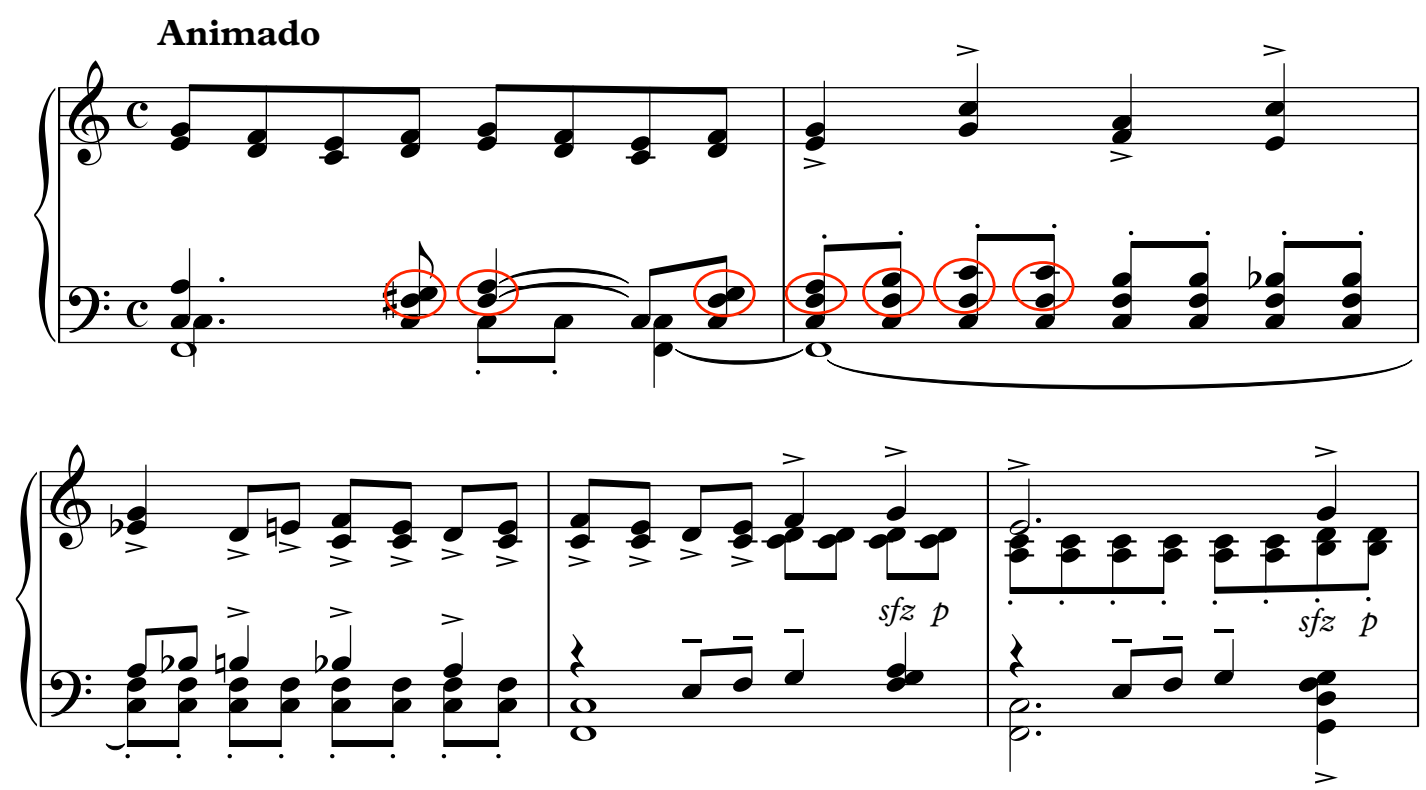

Exemplo 18: Díades com aberturas intervalares cromáticas crescentes e decrescentes em À procura de uma agulha (Ciranda n. 13), de Villa-Lobos (c. 61-65).

Por outro lado, o fato de ter sido orientada por Camargo Guarnieri traz para a composição de Eunice Katunda a valorização do contraponto - como 
CANDIDO, M. et al. O atonalismo, a dodecafonia e a música nacional de Eunice Katunda em Variações sobre um tema popular e Quatro epígrafes

vimos nas variações que apresentam cânones entre linhas melódicas - e mesmo da variação motívica, baseada em procedimentos como aumentação, entre outros. Segundo Barros (2013, p. 8), “a maneira de trabalhar os temas de Guarnieri talvez pudesse ser vista como mais tradicional, apresentando em geral uma construção musical polifônica bastante atada ao elemento motívico".

\subsection{Quatro epígrafes}

A obra para piano Quatro epígrafes é uma transcrição da obra orquestral Cantos à morte, escrita pela compositora em 1946 e estreada na Suíça em 1948 sob regência de Hermann Scherchen, durante a citada viagem com colegas de grupo Música Viva. A transcrição foi criada no Rio de Janeiro em 1948, sendo que sua cópia definitiva registra o ano de 1950. A estreia de Quatro epígrafes foi realizada pela própria compositora em 1948, em Lugano, no I Congresso de Música Dodecafônica.

Vale dizer que Cantos à morte surge no mesmo ano (1946) em que Eunice ingressa no movimento Música Viva e assina o segundo Manifesto, também chamado de Declaração de Princípios. No documento, ela e o grupo de compositores(as) assumem como fundamento que "a arte é o reflexo do essencial na realidade [...] música é movimento [...] que revela o eternamente novo" (Kater 2001b, p. 68).

Os princípios da essencialidade e da novidade estão na base de Quatro epígrafes, composta em 4 movimentos ${ }^{27}$ em estilo aforístico, sendo que cada um deles não possui mais que 15 compassos - 1 Calmo, 2 Agitato rubato, 3 Grave calmo e 4 Agitato molto. Todos os movimentos foram compostos segundo a técnica dodecafônica e a partir de uma única série $\mathrm{O}_{1}\{$ Do\#, Sol\#, Ré\#, Mi, Ré, Sol, Lá, Fá\#, Si, Lá\#, Fá, Do\}, apresentada na Introdução da Epígrafe 1 em textura homofônica (vertical, em acordes) seguida de monofonia (linha melódica horizontal).

\footnotetext{
${ }^{27}$ Optamos por chamar cada Epígrafe de movimento por entender que, como numa grande forma clássica, há uma conexão entre elas a partir da série original $\mathrm{O}_{1}$, como havia no sistema tonal usado em períodos anteriores.
} 


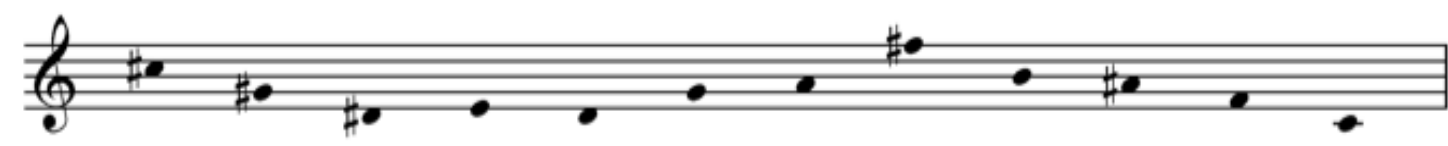

Exemplo 19: Série dodecafônica original empregada em Quatro epígrafes.

Eunice trabalha a série $\mathrm{O}_{1}$ nas quatro possibilidades existentes: original $(\mathrm{O})$, retrógrado da original $(\mathrm{RO})$, inversa $(\mathrm{I})$ e retrógrado da inversa (RI). Pela observação dos procedimentos empregados, é possível notar que ela se preocupou em manter a coerência não somente dentro de cada peça do ciclo, como também entre as mesmas ${ }^{28}$.

Isso se dá no trato da série dodecafônica, única nos 4 movimentos, e também no emprego dos materiais texturais, aqui chamados Material $1 \mathrm{e}$ Material 2. Estes se diferenciam pelo aspecto vertical, em acordes, no caso do Material 1, e horizontal, em linhas, no caso do Material $2{ }^{29}$.

Em relação ao material melódico, nota-se o uso de manipulações das séries ao longo dos movimentos por meio de substituição, inserção, omissão, permutação e/ou elisão de notas, bem como emprego de séries incompletas, entre outros procedimentos característicos da técnica dodecafônica.

Em Epígrafe 1, por exemplo, há omissão da nota Fá (11ํe elemento da serie $\mathrm{O}_{1}$ ) no Material 1 (c. 1-2), sendo que no Material 2 esta nota é apresentada duas vezes, conforme exemplo a seguir.

\footnotetext{
${ }^{28}$ Conforme mencionado, a mesma série dodecafônica $\mathrm{O}_{1}\{\mathrm{D}$ \#́\#, Sol\#, Ré\#, Mi, Ré, Sol, Lá, Fá\#, Si, Lá\#, Fá, Do\} foi empregada nas quatro peças do ciclo, sendo apresentada nas versões $\mathrm{O}_{1}, \mathrm{O}_{8}$, e $\mathrm{RO}_{1}$ em Epígrafe 1, RO1 em Epígrafe 2, I1, I3, RI $\mathrm{I}_{1}$ em Epígrafe 3 e, por fim, $\mathrm{O}_{9}, \mathrm{RO}_{9}, \mathrm{I}_{9}, \mathrm{O}_{11}$ em Epígrafe 4.

${ }^{29}$ Nos exemplos musicais o Material 1 e o Material 2 são demarcados, respectivamente, por uma chave horizontal azul e uma vermelha. Sobre estes materiais texturais se falará após o mapeamento das séries e seu tratamento pela compositora.
} 
CANDIDO, M. et al. O atonalismo, a dodecafonia e a música nacional de Eunice Katunda em Variações sobre um tema popular e Quatro epígrafes

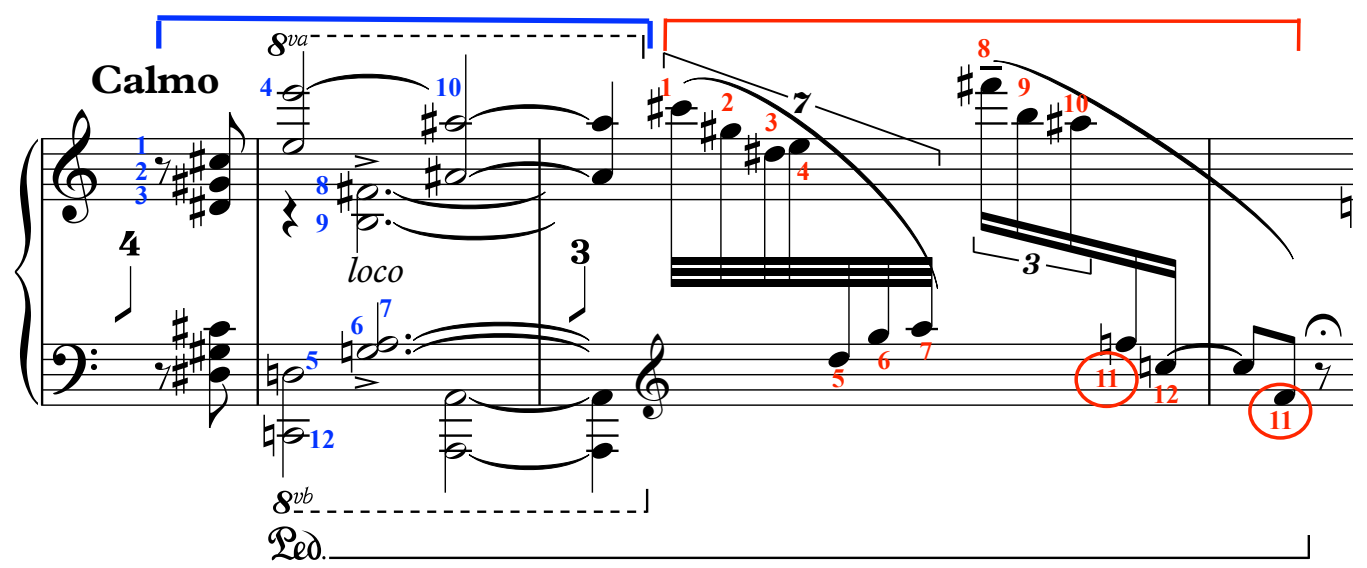

Exemplo 20: Série $\mathrm{O}_{1}$ mapeada na Introdução de Epígrafe 1 (c. 1). Omissão da nota Fá no Material 1 (azul) e repetição do mesmo Fá no Material 2 (vermelho).

Em Epígrafe 2 verifica-se, entre outros elementos, o emprego das séries com omissão, permutação e/ou repetição de algumas notas. Como exemplo temse os compassos 8-9, em que é possível verificar o emprego da série dodecafônica $\mathrm{RO}_{1}$ com omissão do Sib e Ré\#, ou seja, sem o terceiro e décimo elemento da série dodecafônica, assim como a repetição da nota $\mathrm{Mi}$, oitavo elemento da série.

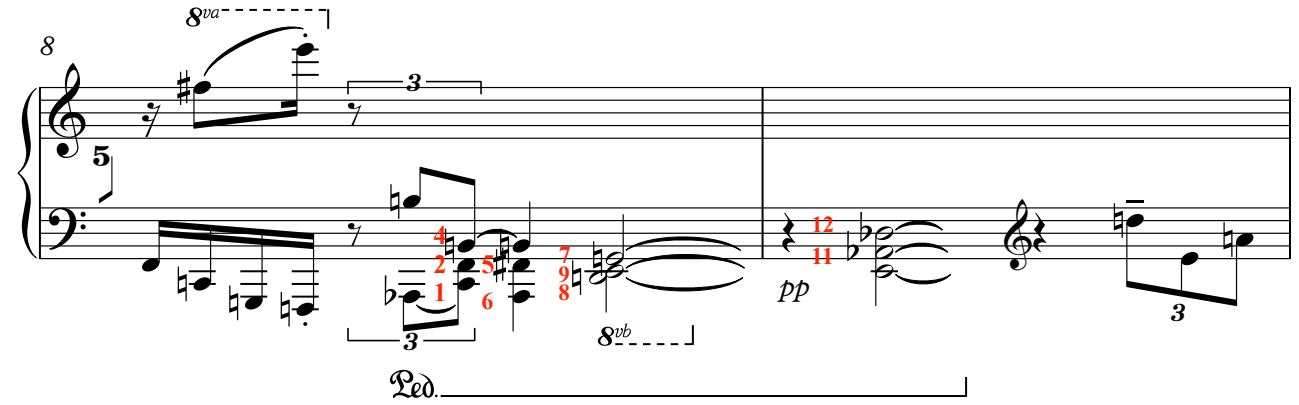

Exemplo 21: Série RO1 mapeada. Omissão do Sib e Ré\# (c. 8-9).

Em Epígrafe 3, além da série dodecafônica ser apresentada no início como nas anteriores (c. 1-2), ela também aparece no início de cada frase. Nos c. 11-12 ela aparece invertida $\left(\mathrm{I}_{1}\right)$, com omissão da $11^{\mathfrak{a}}$ nota (Lá). Outro ponto importante deste trecho é o emprego da técnica de elisão, em que a nota Ré do c. 13 é utilizada como final da apresentação da série $\mathrm{I}_{1}$ e como a primeira da série $\mathrm{RI}_{1}$. 


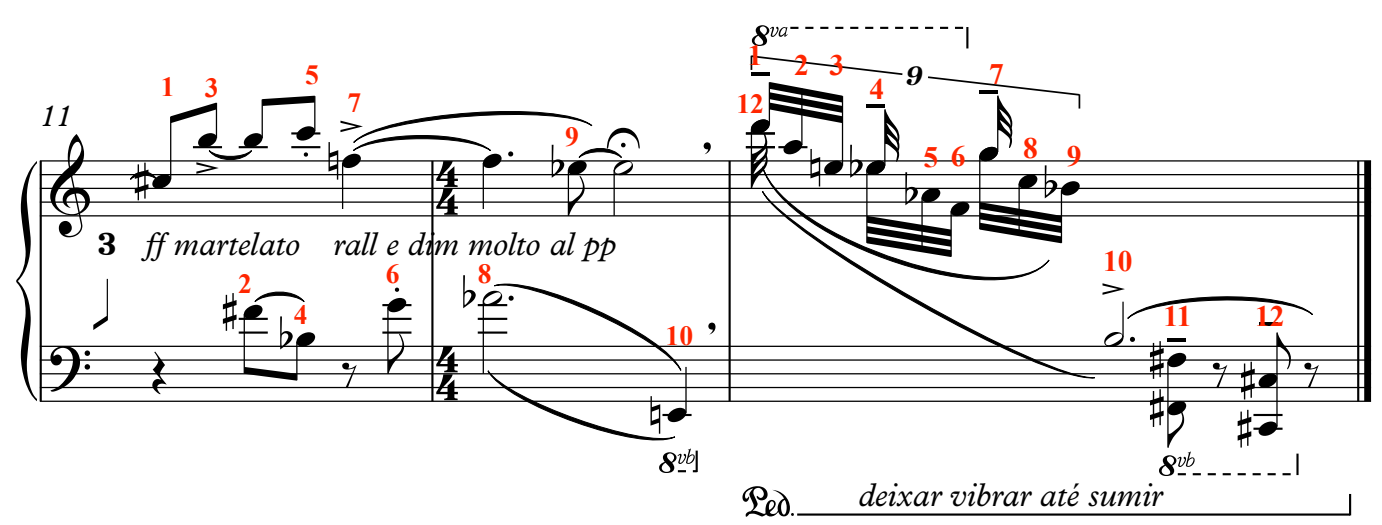

Exemplo 22: Mapeamento da série dodecafônica $\mathrm{O}_{1}$ e $\mathrm{RO}_{1}$ em Epígrafe 3 (c. 11-13).

Por sua vez, as series empregadas em Epígrafe 4 apresentam-se de maneira completa, conforme o exemplo a seguir, e também por meio de procedimentos como a permutação, omissão de notas e alteração cromática.

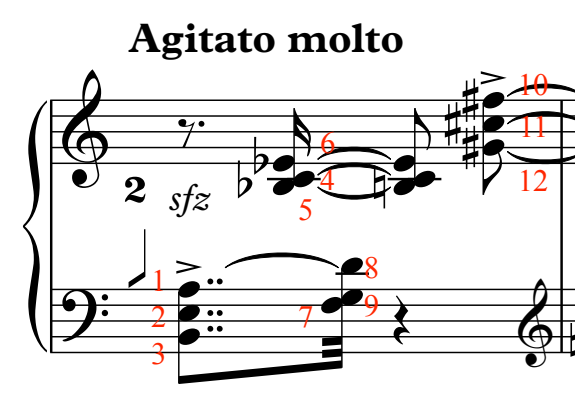

Exemplo 23: Mapeamento da série Os em Epígrafe 4 (c. 1).

A Fig. 1 mostra o mapeamento das séries ao longo da Epígrafe 4, mostrando sua aparição em todos os compassos.

\begin{tabular}{|c|c|c|c|c|}
\hline Versão da Série & Compassos & & & \\
\hline $\mathrm{O}_{9}$ & 2 e $3 \quad 6$ & 7 e 8 & 9,10 e $11 \quad 12$ & 14 \\
\hline $\mathrm{RO}_{9}$ & 4 e 5 & & & \\
\hline $\mathrm{I}_{9}$ & 13 & & & \\
\hline $\mathrm{O}_{11}$ & 14 e 15 & & & \\
\hline
\end{tabular}

Figura 1: Mapeamento das séries dodecafônicas empregadas em Epígrafes 4. 
CANDIDO, M. et al. $\quad \mathrm{O}$ atonalismo, a dodecafonia e a música nacional de Eunice Katunda em Variações sobre um tema popular e Quatro epígrafes

Em relação aos materiais texturais, foram observados o emprego dos Materiais 1 (vertical e homofônico) e 2 (horizontal e monofônico) em Epígrafe 1 e Epígrafe 4, enquanto que a Epígrafe 2 apresentou principalmente elementos do Material 2 e Epígrafe 3, referências do Material 1. Nos primeiros três compassos de Epígrafe 1 é possível observar os dois materiais que são empregados ao longo de toda a peça, sendo o Material 1 apresentado no primeiro compasso e o Material 2 em seguida, nos compassos 2 e 3.

Esses dois materiais texturais podem aparecer justapostos - como na Epígrafe 1 (Ex. 24) -, ou sobrepostos, como na Epígrafe 4 (Ex. 25). O uso destes procedimentos, apontados na análise de Variações sobre um tema popular, demonstra que Eunice Katunda não abandonou totalmente os procedimentos villalobianos de sua Fase de Formação em sua segunda fase composicional.

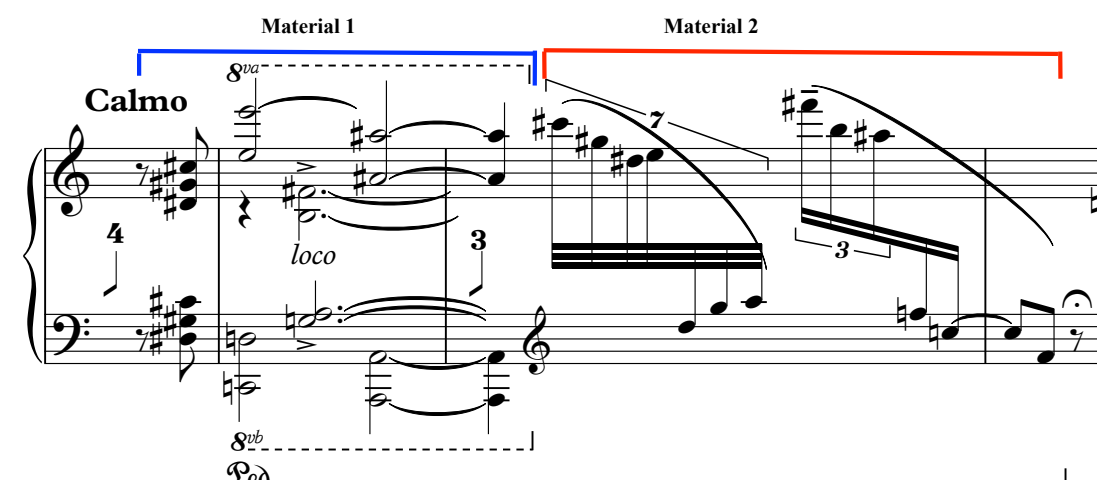

Exemplo 24: Introdução de Epígrafe 1. Material 1 e Material 2 (c. 1-3).

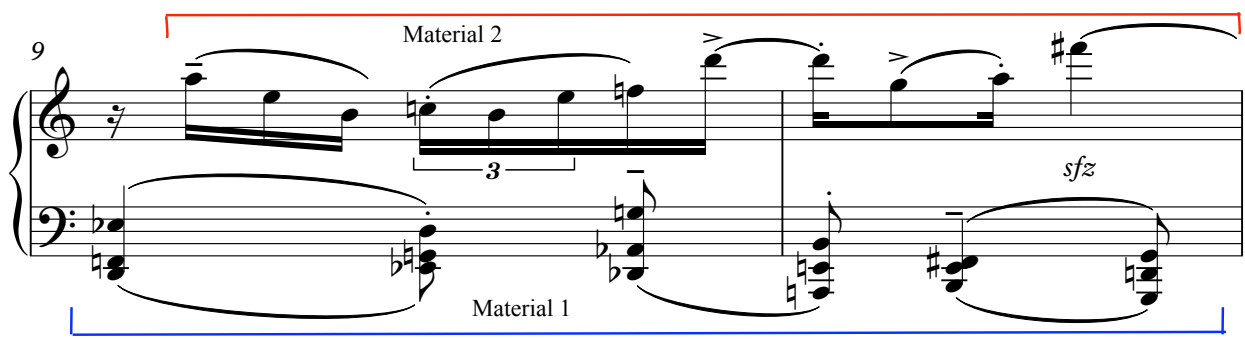

Exemplo 25: Sobreposição de Material I e Material 2 em Epígrafe 4 (c. 9-10).

Como foi dito, na Epígrafe 2 predomina o Material 2, horizontal, como mostra o exemplo a seguir. 


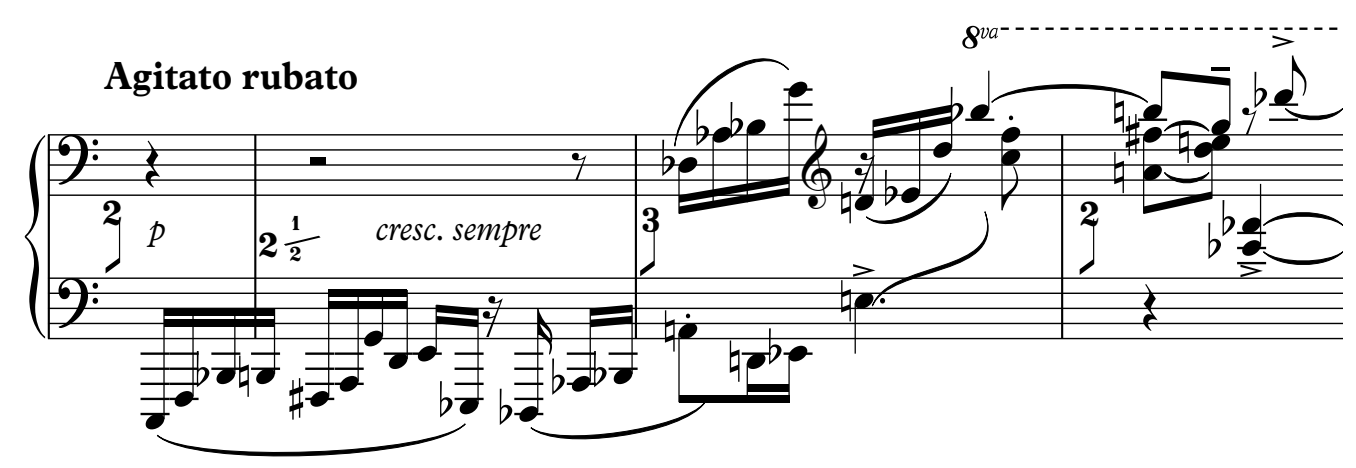

Exemplo 26: Epígrafe 2 (c. 1-3).

E o Material 1 ocupa todos os espaços de Epígrafe 3, como demonstra a Ex. 27.

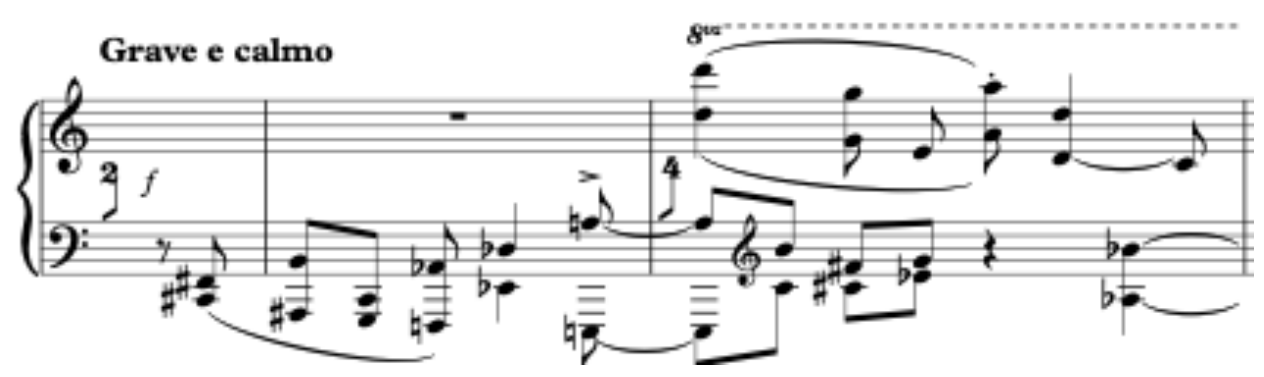

Exemplo 27: Epígrafe 3 (c. 1-2).

\section{Afinal, “é possível fazer música atonal, ou dodecafônica, de caráter nacional?" O dilema de Eunice Katunda}

Após a leitura dos textos escritos por Eunice Katunda e a análise de suas composições das Fases de Formacão e Música Viva, é possível apontar uma continuidade entre as estéticas defendidas pela compositora e as técnicas por ela empregadas. Isso fica mais claro quando comparamos sua obra Variações sobre um tema popular a peças tocadas por ela nos primeiros anos de sua carreira, como as Cirandas de Villa-Lobos, entre outras, ou quando observamos suas Quatro Epígrafes à luz de seu processo de aprendizado com Camargo Guarnieri e, em seguida, com Hans-Joachim Koellreutter.

Outros(as) compositores(as) também marcaram a trajetória da compositora, refletindo-se em suas composições. Durante sua primeira fase estético-composicional, por exemplo, observa-se que suas apresentações de 
CANDIDO, M. et al. $\quad \mathrm{O}$ atonalismo, a dodecafonia e a música nacional de Eunice Katunda em Variações sobre um tema popular e Quatro epígrafes

piano abarcavam um repertório europeu comum à formação de pianistas, além de peças de compositores(as) brasileiros(as) como, por exemplo, de sua professora Branca Bilhar e Heitor Villa-Lobos. Já na Fase Música Viva, verificase que Eunice passou a tocar peças de compositores cuja produção tinha como característica o emprego de modernas técnicas de composição como, por exemplo, Paul Hindemith e a sua peça Ludus Tonalis, assim como obras de compositores do grupo Música Viva, como Guerra-Peixe, Edino Krieger e de sua própria autoria.

Quanto à pergunta “é possível fazer música atonal, ou dodecafônica, de caráter nacional?" - à qual Eunice respondeu primeiramente sim e posteriormente não -, talvez a resposta seja afirmativa se levarmos em conta, por um lado, as palavras de Santoro sobre o uso técnico de conteúdos formadores do material folclórico nacional para a construção de uma escola brasileira de composição, e, por outro, a citação da própria Eunice Katunda sobre o modo villalobiano de compor música nacional.

Disse Santoro (1941, p. 7, apud Mendes 2009, p. 21):

O folclore deve ser dissecado, estudado em sua origem, não histórica, mas técnica, e seu desenvolvimento realizado pelo estudo e não pelo aproveitamento temático. Ter-se-á então, o material necessário para a realização dos tratados de estudo e formação de uma música essencialmente nacional, e por conseguinte da escola de composição brasileira. [...] As formas surgirão e com todo o material é tratar de desenvolvê-lo ao nível da cultura contemporânea.

Já Eunice Katunda diria:

Todo grande artista é sempre, queira ele ou não, produto de uma tradição popular forte, seja ele uma tradição puramente nacional ou ainda (como no caso da Itália, Inglaterra, Alemanha) de um folclore já internacionalizado, já assimilado pelo mundo todo, dada a influência desses países no processo de civilização. Quando o artista tem realmente força expressiva, quando sua sensibilidade e sua necessidade de expressão são verdadeiramente grandes, ele exprime sempre o que nele há de profundamente nacional. Assim é que Villa, apesar de educado musicalmente na tradição europeia, de se exprimir com os meios de expressão musical europeus (os únicos que atualmente temos para fazer música civilizada), o Villa fez música essencialmente brasileira. Porque consegue abrasileirar todos os stravinskismos e impressionismos que não resistem à sua força nacional, força mais poderosa e mais sugestiva que todas as escolas musicais que contribuíram na sua formação como compositor (Katunda 1948, p. 5). 
MUSICA THEORICA Revista da Associação Brasileira de Teoria e Análise Musical 2021, v. 6, n. 1, p. 100-132 - Journal of the Brazilian Society for Music

De acordo com as palavras da autora em seu texto Problemas musicais contemporâneos, entende-se que, para ela, as novas técnicas de composição surgiram da necessidade criativa de compositores e compositoras. Pode, portanto, ser equivocado julgar a presença ou ausência de um caráter nacional simplesmente pelo fato de uma composição apresentar um procedimento novo e/ou pouco conhecido de uma cultura musical em determinada época.

\section{Referências}

1. Assis, Ana Cláudia. 2010. César Guerra-Peixe: entre músicas e músicos (19441949). Em: Revista do Conservatório de Música da UFPel Pelotas, n. 3. Disponível em:

$<$ https://periodicos.ufpel.edu.br/ojs2/index.php/RCM/article/view/2453>.

2. Barros, Frederico Machado de. 2013a. Afinal, quem é o folclore? Villa-Lobos e Guarnieri segundo Guerra-Peixe. Em: Anais do 37º Encontro Anual da ANPOCS. Águas de Lindoia: ANPOCS. Disponível em: $<$ https://anpocs.com/index.php/papers-37-encontro/st/st19/8515-quem-emesmo-o-folclore-villa-lobos-e-guarnieri-segundo-guerra-peixe/file $>$. Acesso em 19/4/2021.

3. Bethell, Leslie (ed.). 1999. A cultural history of Latin America: literature, music and the visual arts in the 19th and 20th centuries. New York: Cambridge University Press (Reprinted).

4. Candido, Marisa Milan. 2017. Estéticas cruzadas: rupturas e deslocamentos em Cláudio Santoro, César Guerra-Peixe e Eunice Katunda a partir de obras para piano compostas entre 1948 e 1952. Dissertação (Mestrado em Música). Campinas: Universidade Estadual de Campinas.

5. Candido, Marisa Milan; Monteiro da Silva, Eliana. 2019. Resenha do livro Eunice Katunda: musicista brasileira, de Carlos Kater. Revista Música (online), v. 19, p. 289-298.

6. Coelho de Souza, Rodolfo. 2011. A recepção das teorias do dodecafonismo nos últimos Quartetos de cordas de Cláudio Santoro. Revista brasileira de música, v. 24, n. 2, p. 329-350. Disponível em: $<$ https://revistas.ufrj.br/index.php/rbm/article/view/29239>. Acesso em $31 / 5 / 2021$.

7. _. 2009. Uma introdução às teorias analíticas da música atonal. Em: Pesquisa em música no Brasil: métodos, domínios, perspectivas, vol. 1. Goiânia: ANPPOM. Disponível em: 
CANDIDO, M. et al. O atonalismo, a dodecafonia e a música nacional de Eunice Katunda em Variações sobre um tema popular e Quatro epígrafes

$<$ https://www.researchgate.net/publication/235224844_Uma_introducao_as teorias_analiticas_da_musica_atonal>. Acesso em 19/4/2021.

8. Ficagna, Alexandre Remuzzi. 2008. Composição pelo som: trabalho composicional e analítico de repertório instrumental por métodos de análise da música eletroacústica. Dissertação (Mestrado em Música). Campinas: Universidade de Campinas. Disponível

em: $<\underline{\text { http://www.uel.br/ceca/musica/pages/arquivos/FicagnaAlexandreRemuzzi }}$ M.pdf>.

9. Fléchet, Anaïs. 2011. As partituras da identidade: o Itamaraty e a música brasileira no século XX. Em: Escritos: Revista da Fundação Casa Rui Barbosa, ano 5, n. 5. Disponível em:

<http://escritos.rb.gov.br/numero05/FCRB_Escritos_5_11_Anais_Flechet.pdf >. Acesso em 18/4/2021.

10. Hartmann, Ernesto. 2010. Claudio Santoro e o II Congresso de Compositores Progressistas de Praga. Em: Anais do I Simpósio Brasileiro de Pós-Graduandos em Música / XV Colóquio do Programa de Pós-Graduação em Música da UNIRIO. Rio de Janeiro: SIMPOM. Disponível em: $<$ http://www.seer.unirio.br/simpom/article/view/2722>. Acesso em $31 / 5 / 2021$.

11. _ 2017. O piano didático de César Guerra-Peixe - uma breve análise dos problemas estilísticos, técnicos e musicais da sua produção de 1942 até 1949. Revista Vórtex, v. 5, n. 3. Disponível em:

<http://periodicos.unespar.edu.br/index.php/vortex/article/view/2165>.

12. Kater, Carlos. 2001a. Eunice Katunda: musicista brasileira. São Paulo: Annablume.

13. __. 2001b. Música Viva e H.- J. Koellreutter: movimentos em direção à modernidade. São Paulo: Musa.

14. __. 2020. Eunice Katunda: musicista brasileira / brazilian musician. 2. ed. São Paulo: M\&K.

15. Katunda, Eunice. [198?]. Curriculum Vitae. Texto datilografado.

16. __ 1950 (abril). Problemas musicais contemporâneos. São Paulo: Cópia de manuscrito cedido pelo neto da compositora, Daniel Catunda Jr.

17. Mariz, Vasco. 2005. História da música no Brasil. 5. ed. ampl. e atualizada. Rio de Janeiro: Nova Fronteira. 
MUSICA THEORICA Revista da Associação Brasileira de Teoria e Análise Musical 2021, v. 6, n. 1, p. 100-132 - Journal of the Brazilian Society for Music

18. Mendes, Sérgio Nogueira. 2009. O percurso estilístico de Cláudio Santoro: roteiros divergentes e conjunção final. Tese (Doutorado em Música). Campinas: Universidade de Campinas. Disponível em: <http://repositorio.unicamp.br/jspui/bitstream/REPOSIP/284014/1/Mendes SergioNogueira_D.pdf>. Acesso em 14/8/2021.

19. Monteiro da Silva, Eliana; Candido, Marisa Milan. 2021. Resenha da $2^{a}$ edição ampliada e bilíngue de Eunice Katunda: musicista brasileira, de Carlos Kater. Opus, v. 27 n. 1, p. 1-13. Disponível em:

$<$ https://www.anppom.com.br/revista/index.php/opus/article/view/opus202 1a2707>.

20. Neves, José Maria. 2008. Música contemporânea brasileira. 2. ed. Rio de Janeiro: Contra Capa.

21. Pascoal, Maria Lucia Senna Machado. 1989. Prelúdios de Debussy: reflexos e projeção. Tese (Doutorado em Música). Campinas: Universidade de Campinas. Disponível em:

<http://repositorio.unicamp.br/jspui/bitstream/REPOSIP/284333/1/Pascoal_ MariaLuciaSennaMachado_D.pdf $>$. Acesso em 14/8/2021.

22. Piedade, Acácio Tadeu. 2007. Expressão e sentido na música brasileira: retórica e análise musical. Revista eletrônica de musicologia, v. XI.

23. Rodrigues, Lutero. 2015. As características da linguagem musical de Camargo Guarnieri. Revista Brasileira de Música, v. 28, n. 1, p. 107-140. Rio de Janeiro: Universidade Federal do Rio de Janeiro.

24. Seixas, Guilherme Bernstein. 2006. A evolução para o ostinato modernista. Cadernos do Colóquio, v. 8, n. 1, p. 1-9. Disponível em: < http://www.seer.unirio.br/coloquio/article/view/115 >. Acesso em 31/5/2021.

25. Silveira, Henrique Iwao Jardim. 2012. Colagem musical na música eletrônica experimental. Dissertação (Mestrado em Música). São Paulo: Universidade de São Paulo. Disponível em:

$<$ https://www.teses.usp.br/teses/disponiveis/27/27157/tde-07032013165026/pt-br.php>. Acesso em 14/8/2021.

26. Souza, Iracele Vera Lívero. 2009. Louvação a Eunice: um estudo de análise de obras para piano de Eunice Katunda. Tese (Doutorado em Música). Campinas: Universidade Estadual de Campinas.

27. Vasconcelos, Rodrigo de Carvalho. 2014. Coleções referenciais do Mikrokosmos de Bartók e da Prole do Bebê n. 1 de Villa-Lobos. Dissertação (Mestrado em Música). São Paulo: Universidade de São Paulo. Disponível em: 
O atonalismo, a dodecafonia e a música nacional de Eunice Katunda em Variações sobre um tema popular e Quatro epígrafes

$<$ https://www.teses.usp.br/teses/disponiveis/27/27157/tde-16072015154149/pt-br.php>. Acesso em 18/4/2021.

28. Zani Netto, Amilcar; Monteiro da Silva, Eliana; Candido, Marisa Milan. 2019. A composição de Eunice Katunda no contexto político e musical brasileiro. Revista Extraprensa, v. 12, p. 114-137. Disponível em:

<https://www.revistas.usp.br/extraprensa/article/view/157504/155179>. 